\title{
Determining the KPIs of the German engineering industry based on the evaluation of contemporary business models
}

\author{
Konstantin B. Kostin \\ Saint-Petersburg State University of Economics, St. Petersburg, Russia \\ Kristina Steinbiß \\ ESB Business School - Reutlingen University, Reutlingen, Germany \\ Oliver Petrinovic \\ ESB Business School - Reutlingen University, Reutlingen, Germany
}

\begin{abstract}
This study determines the correlation between industry-specific success patterns of the German engineering industry and the business models applied within. In order to identify this correlation, the following objectives are addressed within the framework of this paper: (1) identification and description of business models used by the German engineering industry; (2) analysis of industry-specific success patterns of the German engineering industry by the usage of Key Performance Indicators (KPIs); and (3) determination of correlation between the KPIs and the effectiveness of the business models of the German engineering industry These objectives are mainly achieved by literature research and expert surveys. The findings highlight the KPIs (overall 41) that are relevant for the respective business models. This enables a better understanding of the interrelationships of the business model, in order to derive relevant conclusions. The paper contributes to the literature as it advances this field of research in Germany, and it is one of the first studies to examine the relationship between business models and industry-specific success patterns with relevant KPIs.
\end{abstract}

\section{Keywords}

KPIs, business model, business model evaluation, the German engineering industry, industry-specific success patterns.

\section{Introduction}

Most of the great success stories of companies are not so much based on one new ingenious product, but their success can be traced back to their innovative business modell (Gassmann, Frankenberg, \& Csik, 2017, p. 5). The companies' business model has not only changed traditional markets and redefined customer needs but it has also turned the way companies do business upside

\footnotetext{
The term business model is explained in more detail in section 1 . Until then, the business model can be understood as a simplified representation of the holistic business activity.
}

down (Ulrich \& Fibitz, 2017, p. 32). For example, Amazon became the largest bookseller in the world despite the lack of experience in the distribution of books and without its own retail shop (Palumbo, 2019). Tesla has also established a seemingly unassailable lead over the competition by vertically integrating its supply chain of key components, such as charging stations, batteries, AI (Artificial Intelligence) chips or the operating system software, instead of sourcing them out to external suppliers (Montgomery, 2019).

The business models are becoming the basis for discussion of new challenges in business 
practice. The need for discussion stems from the growing changes in the competitive environment, in terms of continuously blurring borders between industry and companies (Zimmermann, 2013). These changes are caused, among other things, by shorter product life cycles and the faster diffusion of technologies and thus demand an extension of the resource- and market-oriented approach of strategic management (Zimmermann, 2013). According to Jansen and Mast (2014, p. 29), these changes often trigger crises and emergency situations at companies, which make it necessary to change or adjust their own business models. Numerous studies and analyses focus on business models in the context of innovation and the necessity for companies to permanently adapt their own business model to internal and external industry impulses in order to ensure long-term competitiveness (Zollenkop, 2006; Ulrich \& Fibitz, 2017; Becker, Ulrich, \& Stradtmann, 2018). In this context, corporate strategy is understood as the link between the current and the targeted business model (Becker, Ulrich, \& Stradtmann, 2018, p. 14). Questions regarding the implementation, life cycle and success requirements of business models are discussed at various points, but usually assume an adaption or adjustment of the underlying business model in the form of innovations (Zollenkop, 2006; Becker, Ulrich, \& Stradtmann, 2018; Born, 2018; Schallmo, 2018).

In contrast, the area of business model evaluation criteria is considered one of the least mature research areas (Pateli \& Giaglis, 2003, p. 343; Horsti, 2007, p. 3). The common evaluation methods can be defined using qualitative criteria, which usually build on existing frameworks. These frameworks address specific questions about individual elements of a business model or quantitative criteria, which are based on the earnings of the company in the context of interaction with customers and suppliers (Heim \& Linden, 2012). Whether the applied business model is ideally executed within the underlying industry or shows any potential for adaptation could not be found in the literature. In fact, Zollenkop (2006, pp. 17-18) states that there are no existing correlations between industry structural characteristics and business models in terms of relevance and success. Although a company's ability to deal with environmental requirements resulting from customers' needs or technology trends, it is considered a cornerstone for the effective use of business models (Born,
2018; Heim \& Linden, 2012). Usually, the analysis of the environment or stakeholders is company-specific and helps the company to break down the overall market into manageable segments. There are proven methods of environmental analysis in the corporate context, such as Michael E. Porter's microeconomic analysis $^{2}$ or the macroeconomic PESTLE (Political, Economic, Social, Technological, Legal and Environmental) Analysis ${ }^{3}$. However, the general industry-specific factors or patterns for success ${ }^{4}$ and their impact on business models are hardly considered, even though the applied business models are placed in the corporate context and adapted to the stakeholders within the industry (e.g. customers, suppliers, competitors) (Leshchenko \& Ermolovskaya, 2019). For example, the demand for flexibility of construction companies is a prerequisite that every successful supplier of construction equipment must meet. Conversely, this leads to the conclusion that a short delivery time for construction equipment is the foundation for being successful within this industry, which results in an industry-specific success factor. According to a survey conducted by McKinsey \& Company $(2016$, p. 38), shorter delivery time is only one among the 10 most important success factors of the of construction equipment industry.

The purpose of this paper is to address the described research gap, by identifying industryspecific success patterns and linking them to the business models applied within the German engineering industry.

Therefore, the main goal of this study could be formulated as follows:

Correlation of differently relevant KPIs, derived from industry-specific success patterns, to Germany's engineering industry's business models in order to evaluate these.

The focus within this paper is on commonly used business models within the observed

\footnotetext{
${ }^{2}$ Five-force model according to Porter, M. E. (1980). Competitive strategy. Techniques for analyzing industries and competitors (52. printing). New York: Free Press

${ }^{3}$ The PESTLE Analysis is a modification of the ETPS or STEP analysis by Francis J. Aguilar (1967) and stands for Political, Economical, Social, Technological, Legal and Environmental factors.

${ }^{4}$ The term industry-specific success factor is explained in more detail in Section 1. Until then, these can be understood as a simplified description of factors that can be influenced and that have a lasting and longer-term positive influence on the success of a company.
} 
industry, as the German engineering industry is suitable for this study due to its century-long history and its archetypal business models (McKinsey \& Company and VDMA, 2016).

The remaining sections of this paper are as follows: First, we specify and describe business models used by the German engineering industry, based on a literature research and an expert survey (section 2). Secondly, we analyse industryspecific success patterns of the engineering industry of Germany by the usage of Key Performance Indicators (KPIs) based on literature research. These analyses are built on the understanding of business models in general and within the German engineering industry, business model evaluation, and industry-specific success patterns, which are briefly discussed in the theoretical background part (section 1). Finally, we will identify the correlation between the determined performance indicators and the underlying business models using an expert survey (section 3 ). The paper concludes with the summary and discussion of the main findings, and provides an outlook of potential research ideas.

\section{Theoretical background}

\subsection{Business models}

Osterwalder, Pigneur and Tucci (2005, p. 4) identified the initial usage of the term "business model" in an academic article in 1957, which was then further recognized through the Internet in the 1990s. During the 1970s, this term was mainly used to describe the result of business modelling in the field of business informatics, which basically captured certain information in the context of the company in order to be able to display the business processes (Zollenkop, 2006, p. 27). Through the expansion of the new economy, this term was redefined as a strategic perspective (Heim \& Linden, 2012, p. 5). This renewed idea was particularly relevant in the field of start-ups, where the way of thinking in business models terms became increasingly popular, since it allowed to differentiate themselves from the competition and to create business plans as demanded by the venture capital companies (Zollenkop, 2006, pp. 29-30).

There is no uniform understanding of a business model, even though it has been the focus of closer examination for years, of strategic and management topics such as corporate performance, value creation, and innovation management (Zott, Amit, \& Massa, 2011;
Osterwalder, Pigneur, \& Tucci, 2005). Heim and Linden $(2012$, p. 4) observed that in many cases the definition is not specified within the literature, because these authors regard it as selfexplanatory, which leads to varied interpretations. When authors explain the term, the perspectives vary greatly from each other. Some authors refer specifically to the way a company operates, while others use it to simplify the complexity of business to an understandable dimension (Osterwalder, Pigneur, \& Tucci, 2005, p. 3). The fact that the authors conduct their research mainly isolated (Zott, Amit, \& Massa, 2011, p. 1034) and not based on one another (Osterwalder, Pigneur, \& Tucci, 2005, p. 22) enhances the different perceptions. According to Bornemann (2010, p. 17 ), the focus of a study is the main reason that the definitions do not only differ from each other, but also sometimes even contradict each other. This different perception is further increased by the usage of the same term to address a wide variety of topics such as e-business, value creation, innovation management (Zott, Amit, \& Massa, 2011, p. 1034) or to describe a company's strategy (Magretta, 2002, p. 91). Another factor for the different perspectives is the varying views of people in business and technology (Osterwalder, Pigneur, \& Tucci, 2005, p. 1). Bornemann (2010, p. 18) claims that the general lack of research in this area as another important factor. This idea is supported by Chesbrough and Rosebloom (2002, p. 533). They identified the lack of focus of business models as the reason for minimal scientific interest.

As a result of a minimal uniform understanding of business models, the literature has numerous comparisons of the different business model definitions, concepts and intensive studies (Zott, Amit, \& Massa, 2011, pp. 1034-1036; Schallmo, 2018, pp. 14-16; Pateli \& Giaglis, 2004, p. 305; Morris, Schindehutte, \& Allen, 2005, p. 728).

For the concept of business models within this paper, we will use the definition identified by Gassmann, Frankenberg and Csik (2017) - the St. Gallen Business Model Navigator. It is the result of an analysis of 250 business models in different countries, in which 55 patterns were identified, that were used as the basis for business model innovation. Gassmann et al. determined via the evaluation phase of their model that $90 \%$ of all new business models are based on a recombination of existing elements and designs. Due to the simple and holistic design of the 
model, which facilitates the description of business models in general, it is a helpful tool to describe and compare the business models to be investigated in the further course of the analysis. Despite its simplified structure, the model succeeds in making the business model concrete and tangible by focusing on the following four dimensions: target customer, value proposition, value chain and revenue model (Figure 1).

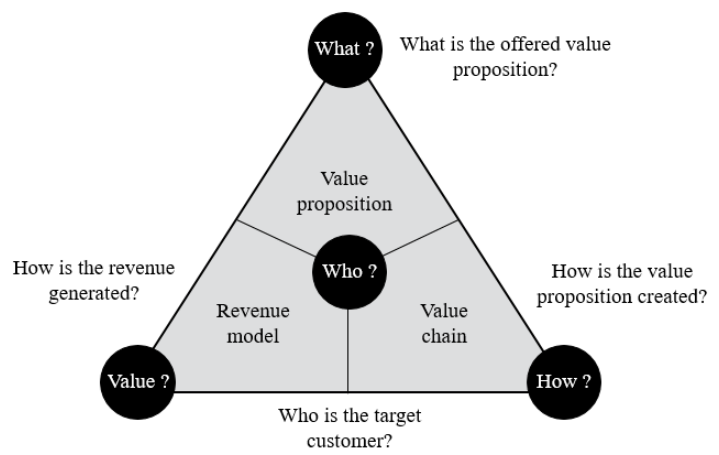

Figure 1 The "magic triangle" with the four dimensions of a business model

Source: Designed based on Gassmann, Frankenberg, \& Csik, 2017

These dimensions allow the customer (Who?) to be placed at the centre, as customers are the cores of every business model. The second dimension (What?) describes the value proposition offered by the company, which can be products as well as services. In order to create and deliver the value proposition, a company has to manage multiple processes and activities within their available resources, skills and internal value chain. All these attributes present the third dimension (How?). Lastly, the revenue model of the business model with all related costs and the underlying revenue mechanism is summarized in the fourth dimension (Value?).

\subsection{Business models of the German engineering industry}

Since the business models of the German engineering industry are quite traditional, there is a moderate number of literature sources to consider. These business models mainly focus on improving technologies and quality. They are also customer-centric with a high degree of individualization (Demont \& Paulus-Rohmer, 2017, p. 104). Demont and Paulus-Rohmer (2017, p. 105) describe these business models with generic terms by using the dimensions of customer segment, value proposition (e.g. problem solving or product/service), revenue creation, value creation (e.g. key activity, competence, partner) and boundary conditions (e.g. legal requirements). A combination of products and services represent their main value proposition (Dr. Wieselhuber \& Partner GmbH \& Fraunhofer-IPA, 2015, p. 22), which addresses very diverse customer segments ranging from automotive manufacturers to food producers (Demont \& Paulus-Rohmer, 2017, p. 105).

Demont and Paulus-Rohmer (2017, p. 106) identify service offering expansions and the associated development of new business models through digitization, as a logical consequence of falling profits from the traditional equipment business. Due to the context of the $4^{\text {th }}$ Industrial Revolution ${ }^{5}$, the business models within this industry draw the attention of different considerations. For example, Gerl (2020, p. 2) justifies the necessity of implementing smart service $^{6}$ business models in this industry, with the opportunity to generate additional sources of income and competitive advantages through differentiation and the increase of customer loyalty. Brauckmann (2015, p. 7) moves a step further by stating that the need for networking systems is essential in order to meet the customer's constantly changing demands. This is illustrated by the fact that production factors such as labour, inputs and materials, are no longer sufficient to describe the entire value chain, since the underlying networks are dynamic and can no longer be managed by traditional measures (e.g. sales, turnover, profit).

Voigt, Arnold, Kiel and Müller (2019) have found that some dimensions of the existing business models of the involved companies have already changed due to the influence of digitization. Frequently observed changes include their value proposition, key resources and activities, and their customer relationships. In the future, the establishment of a consistent aftersales service model will be increasingly important to successfully implement Industry 4.0 business models (Dr. Wieselhuber \& Partner GmbH \& Fraunhofer-IPA, 2015, p. 47). Here, the emphasis is on the creation of a corresponding value

\footnotetext{
${ }^{5}$ The $4^{\text {th }}$ industrial revolution strongly focuses on automation, the interconnectivity of machines and the digitalization of production equipment based on real-time data (also known simply as Industry 4.0).

${ }^{6}$ There is no uniform definition of the term smart service. However, Gerl (2020, pp. 14-16) describes the term as a service that is based on data and creates added value by digitizing processes.
} 
proposition, which is achieved through the combination of open hardware and software. Their provision will presumably be shaped by services platforms, which form the underlying infrastructure use to deliver these to the customer.

\subsection{Business model evaluation}

In this section, quantitative and qualitative evaluation methods of business models are analysed. The qualitative methods can be considered as direct evaluation methods, as these usually address components of the underlying business model directly. The quantitative methods can be considered indirect, because these mainly consider the success of the company and the related business model usually indirectly as a conclusion.

As mentioned above, the field of business model evaluation is minimally researched (Osterwalder, Pigneur, \& Tucci, 2005, p. 8). This fact is supported by the statement: "A 'strong' business model can be managed badly and fail, just as much as a 'weak' business model may succeed because of strong management and implementation skills" (Osterwalder, Pigneur, \& Tucci, 2005, p. 8). In other words, a business model itself may not be as important as its execution. However, the literature is addressing this gap in determining the value of the business model versus its execution. Various approaches to business model evaluation can be found in the literature, mostly applying qualitative and quantitative criteria. Heim and Linden (2012) describe these criteria either by qualitative elements, which are directly related to the business model, or by quantitative factors, which consider financial aspects in the business context. Pateli and Giaglis (2003, p. 310) share a similar view, as they identify the retrospective analysis as the focal point of business model evaluation with multiple possible objectives, such as the opportunity to uncover and evaluate potential business model innovations with quantitative and qualitative elements.

\subsubsection{Qualitative evaluation methods}

In the context of qualitative evaluation methods, Osterwalder and Pigneur (2011, pp. 220-227) assess a business model by rating the nine components of the underlying business model canvas $^{7}$, using a SWOT-analysis including a

\footnotetext{
The nine components of the business model canvas are: customer segments, value proposition, customer relationship,
}

scoring matrix. Zott and Amit (2010) use four design themes, NICE (Novelty, Lock-In, Complementarities and Efficiency) to describe the success criteria for business models as the main value creation driver. Bornemann (2010) also carries out the evaluation of business models by using the 4 business model design themes according to Zott and Amit (2007, Amit \& Zott, 2001), each of which is defined by 9 to 15 indicators, together with indicators for environmental influences (uncertainty and competition intensity) as well as corporate success. For this purpose, Bornemann weighs the significance of the individual indicators to identify quantitative relationships between them. The environmental influences are considered on the success of the company, before the influence of the respective business model design is determined.

Horsti (2007) discusses an evaluation tool for e-business, which uses two different types of success factors (the prerequisites of success and the measures of success). The latter are further categorized into seven components of the ebusiness model (e.g. customer, competitors, resources) and rated with a factor. Horsti (2007, p. 43) describes the tool as a prioritized checklist for a specific business model including the most important issues, which also enables the comparison of different business models. Afuah and Tucci (2003) also use qualitative criteria as they define "component attribute measures" (e.g. positioning, value, activities) to evaluate a business model, by using subjective benchmark questions related to the measures and rank them from high or low.

Schallmo (2018) proposes to evaluate a business model by examining the expected profitability of the business model prototypes depending on different scenarios. For this purpose, critical success factors (time, costs, quality and flexibility) are adapted to the respective business model, their interdependency is determined, and finally different scenarios are derived which describe possible future outcomes. Bouwman, De Vos and Haaker (2008) use their STOF business model (Service domain, Technology domain, Organization domain and Finance domain) as the foundation in terms of designing and evaluating a business model. Firstly, critical success factors (e.g. defined target group, quality of product, value proposition)

channels, key activities, key resources, key partners, cost structure and revenue streams (Osterwalder \& Pigneur, 2011). 
within each domain are identified, while they influence the value for the desired customer and the involved network that includes all actors, which interact and create joint value. Then a relationship is generated between critical success factors and critical design issues (important design variables of a business model) to identify a possible influence. As a consequence, critical design issues may be addressed to consciously influence the success factors.

The literature reviewed here supports the statement that the methods of a business model's qualitative evaluation are often based on a previously developed concept and address specific questions regarding its individual components (Heim \& Linden, 2012, p. 15).

\subsubsection{Quantitative evaluation methods}

Afuah and Tucci (2003) define two quantitative criteria, profitability measures (e.g. earnings, cash flow) and profitability predictor measures (e.g. margins, market share), which consider the success of the company for business model evaluation. Another opportunity to evaluate a business model is addressed by Osterwalder et al. (2005, p. 14) and Born (2018, p. 16), as a balance scorecard $^{8}$ is suggested to improve relevant financial, operational and organizational measures of the related company. Schallmo (2018, p. 241) also discusses financial key figures (Subic, Vasiljevic, \& Andrei, 2010) in the corporate context as an opportunity for a quantitative evaluation.

A similar approach is the $\mathrm{e}^{3}$-value model (ontology) of Gordijn and Akkermans (2003), which visualizes with the help of Use Case Maps ${ }^{9}$ the network of the exchange relationship of all involved actors of the considered business model. Based on the displayed network, all possible expenses and revenues of each actor as well as the value objective, which is handed over between them, is calculated and leads to the profitability of each actor.

Other authors, such as Sandrock (2006) and Grasl (2009) use the simulation method system dynamics $^{10}$ to evaluate business models.

\footnotetext{
The balance scorecard is a set of performance measures with different perspectives (customer, internal, innovation and financial) which provides a clear view on the company's business and helps to focus on the most critical indicator of the present and future performance (Kaplan \& Norton, 1992).

${ }^{9}$ The term Use Case Maps is discussed in detail by Buhr (1998).

${ }^{10}$ System dynamics (initially called industrial dynamics) was
}

Sandrock (2006) applies the method to evaluate the suitability of the business model of an elearning provider and to identify model-induced recommendations for action, which can be used to align the strategy of the company. For this purpose, various variables and constants that describe the business model and its influencing parameters are defined before the simulation is applied. Then the model structure and relevant behaviour are validated to confirm the correctness of the assumptions and correlations. Grasl (2009) has a similar approach, as he declares the recommendations, which are derived by questions and scenarios concerning the related business model, as the main goal of business model analysis. The method engineering metamodel ${ }^{11}$ is used to design the architecture and behaviour of business models. The architecture defines how suitable relevant individual components are for respective business model as well as their relationship to each other. Behaviour, on the other hand, defines how the components interact and how their value develops over time. The simulation method system dynamics provides valuable information about future events and the resulting measures of the analysed business models. However, they neglect a current state evaluation of the business model, since they focus on future developments that assume their analysed business model is effective. Thus, it is not possible to identify unused potentials of the business model.

Usually, the quantitative evaluation analysis indirectly evaluates the underlying business model since the actual evaluation is based on financial key figures of the associated company. An additional consideration is that the quantitative evaluation method could be very limited, because it mainly focuses on difficult to measure financial indicators (Pateli \& Giaglis, 2004, p. 310).

\subsubsection{Conclusions for the evaluation methods}

As discussed in the previous section, various qualitative and quantitative methods have been identified in the literature for business model evaluation. Despite the differences identified, all methods have one thing in common: the effectiveness of the business model is evaluated. This means they evaluate how well the business

developed by Forrester (1968) and describes a simulation method for the analysis of complex, non-linear and dynamic systems.

11 The business engineering model is discussed in detail by Österle and Winter (2003). 
model copes with the expectations and influences in the corporate context. In other words, the effectiveness of the business model is evaluated in the business context. All examined methods assume a completely efficiently implemented business model that leaves no room for unused potential. There was no referenced literature addressing questions regarding the efficiency of implementation, control or further development of business models.

\subsection{Industry-specific success factors}

First, the idea of success factors will be addressed in this section in order to determine a suitable definition of the term industry-specific success factor. The first serious investigations in the field of success factor research can be dated back to the 1960s to 1970 s (Becker \& Ulrich, 2011, p. 84). Through the Profit Impact of Market Strategies (PIMS) research program, which was started in 1972 by the Marketing Science Institute of the Harvard Business School, success factor analysis has undergone a considerable development (Spelsberg, 2011). Capon, Farley and Hoenig (1990) analysed the success of companies in terms of financial performance using a meta-analysis based on empirical work. They examined, among other things, which central independent variables were used to explain the success of the company. In the process, they were able to identify differences between the various variables in terms of their probability, strength and influence on the company's success. In this context Nicolai and Kieser (2002, p. 580) describe success factors as influencing variables which are responsible for the success of the company and which are suitable for the derivation of a recommended strategy for the management. A similar description is provided by Boeing (2001, p. 10), who describes success factors as determinants that effectively influence the success of a company in the long term. These establish a competitive advantage and are regarded as valuable orientation in strategic corporate planning. In contrast, Daschmann's (1994, p. 1) formulation is more general, as only characteristics or structures that have a positive influence on the success of the company are named. In this context, the differences between critical $^{12}$ and strategic ${ }^{13}$ success factors are also

\footnotetext{
${ }^{12}$ Critical success factors have a higher weight than non-critical ones, which should lead to a reduction in the number of interrelationships within the scope of the study (Daschmann, 1994, p. 11).
}

mentioned. These examples overall illustrate a general understanding of success factors within the literature.

Although different authors have conducted the research on success factors for decades, the results so far are inconclusive, as they are generally contradictory (Woywode, 2004; Nicolai \& Kieser, 2002). As a possible reason, Woywode (2004) points to the focus of the investigations on only few central key variables in the company instead of large-scale surveys of the entire company context. This could also be related to the lack of investigation of factors that have a negative impact on the company's success (Capon, Farley, \& Hoenig, 1990, p. 1158). Nicolai and Kieser (2002) identified methodologically demanding quantitative-empirical studies as the main contribution to elaborate success factors. One factor for the research's ineffectiveness may be the insufficient application of methodological standards. Examples of these shortcomings include the usage of unrepresentative samples, inappropriate statistical methods and the misinterpretation of the causal relationship of cross-sectional data (Nicolai \& Kieser, 2002, p. 584). Additional common methodological shortcomings include the revealing of causal structures, conducting data collection and implementing data analysis (Spelsberg, 2011, p. 33). Another difficulty of success factor research is the different definitions of the success measure to determine the success of a company. These definitions include profit development, market share and return on investment or the return on equity (Woywode, 2004, p. 22). Daschmann (1994) identifies the confusing variety of influencing variables and conditions as the reason for the lack of systematization of the results in success factor analysis. On the one hand, industry, company- and business area-specific success factors are mentioned. On the other hand, success factors in the context of performance, position, market and product are described.

It can be stated that there is a general understanding of the definition of success factors in the literature, which is adapted to this study. Furthermore, there is great disagreement regarding the results of the success factor analysis and the methodologies used. Proposals for investigations are described in various studies, for example by Nicolai and Kieser, as well as by

\footnotetext{
13 Strategic success factors describe dynamic influences that should have a lasting and long-term impact on the success of a company (Daschmann, 1994, p. 11).
} 
Woywode. As a possible approach to identifying success factors on an empirical basis, Nicolai and Kieser (2002, p. 586) suggest that researchers must make assumptions on causal relationships based on an explicit or implicit theory. Woywode (2004, p. 41) proposes to combine quantitative and qualitative methods within the framework of success factor research, to overcome the limitations of the results regarding interpretability and applicability.

Based on the general understanding of success factors, the term industry-specific success factors describes factors which should secure the company's success in the long term and apply primarily to the examined industry. The current singular explanation for success factors is insufficient to explain success alone. Hence, the concept of success patterns represents success's complexity better, especially when viewed holistically.

\section{The German engineering industry}

The following section addresses the business model archetypes of the German engineering industry and their value chain (section 2.1). This analysis describes the basic features of the applied business models within the industry and thus forms the first step of their determination. The literature of the VDMA (Verband Deutscher Maschinen- und Anlagenbau - Mechanical Engineering Industry Association) is primarily used for research, as it is the largest network organization with around 3300 members with significant influence on the engineering industry in Germany and Europe. It represents the mutual economic, technical and scientific interests of this diverse industry (VDMA, 2020). Most of the underlying literature consists of surveys as well as quantitative data collection from companies of the German engineering industry. Figure 2 shows the linear steps of determining the business models and KPIs of the German engineering industry.
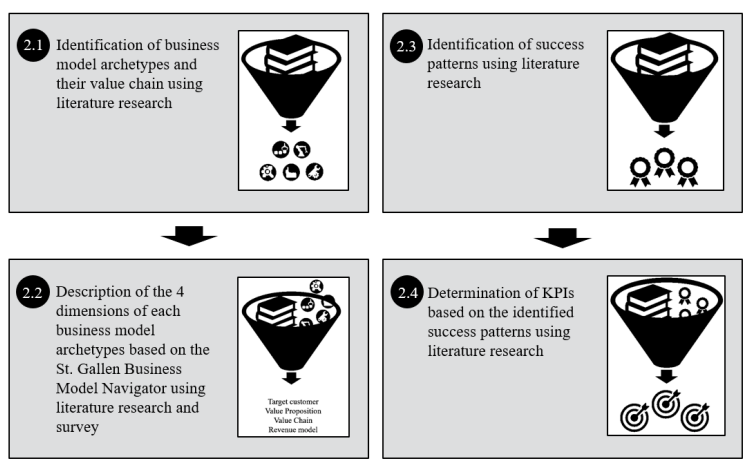

Figure 2 Methodology of the determination of the German engineering industry's business models and KPIs Source: The authors

Section 2.2 outlines the identified business models utilizing the St. Gallen Business Model Navigator. These outlines are based on the results of section 2.1 and are determined using qualitative literature review. VDMA's literature is the basis for this analysis, as it focuses on the business models of the German engineering industry. The four dimensions of the business models of the German engineering industry are described by using St. Gallen Business Model Navigator's description of a business model and the results of the literature review. However, one of the dimensions, revenue model, could not be determined by literature research. As such, a quantitative survey was conducted with experts of the related industry. These experts are directly involved in the procurement or sales of components, machines, aftersales and software applications, and possess several years of professional experience in this field.

Subsequently, the success patterns of the engineering industry of Germany are determined (section 2.3) and analysed by the usage of KPIs (section 2.4). In order to identify the success patterns within the industry, an analysis of various quantitative studies on this subject is carried out. Finally, the KPIs are determined based on the identified success patterns using qualitative literature research.

\subsection{Business model archetypes and their value chain}

The business models of the present engineering industry are illustrated by the study of McKinsey \& Company and the VDMA in 2016 (McKinsey \& Company and VDMA, 2016). McKinsey \& Company and the VDMA analyse the primary business models of 215 European companies (135 of them German) in a broad range of industry sectors (Table 1). 
Table 1 Participants of the various industry sectors

\begin{tabular}{|c|c|}
\hline Industry sector & $\begin{array}{l}\text { Number of respondents by } \\
\text { industry sector (multiple } \\
\text { choice), } n=215\end{array}$ \\
\hline Power Transmission Engineering & 41 \\
\hline $\begin{array}{lcc}\text { Machine } & \text { Tools } & \text { and } \\
\text { Manufacturing Systems } & \end{array}$ & 32 \\
\hline Food Processing and Packaging & 28 \\
\hline Electrical Automation & 23 \\
\hline Robotics + Automation & 23 \\
\hline $\begin{array}{ll}\text { Large Industrial } & \text { Plant } \\
\text { Manufacturing } & \end{array}$ & 22 \\
\hline $\begin{array}{l}\text { Construction Equip. and Building } \\
\text { Mat. Machines }\end{array}$ & 20 \\
\hline Engines and Systems & 19 \\
\hline Process Plant and Equipment & 17 \\
\hline Precision Tools & 16 \\
\hline Plastics and Rubber Machinery & 15 \\
\hline $\begin{array}{l}\text { Printing \& Paper Equipment and } \\
\text { Supplies }\end{array}$ & 15 \\
\hline Fluid Power & 13 \\
\hline Agricultural Machinery & 13 \\
\hline $\begin{array}{l}\text { Materials Handling and Logistic } \\
\text { Technology }\end{array}$ & 13 \\
\hline $\begin{array}{l}\text { Measuring and } \quad \text { Testing } \\
\text { Technology }\end{array}$ & 13 \\
\hline Foundry Machinery & 12 \\
\hline Security Systems & 12 \\
\hline Pumps + Systems & 12 \\
\hline
\end{tabular}

Source: Designed based on McKinsey \& Company and VDMA, 2016, $p$.

Five business model archetypes with their own distinct characteristics are defined (figure 3). These archetypes are based on the classification that a company earns more than $50 \%$ or $20 \%$ of their overall revenue within a particular part of the industrial value chain. Depending on the business model's focus and the industry sector affiliation, one archetype can include various business models. The variations are significantly influenced by the depth of the company's net value added and its own position within the entire value chain. In order to obtain reliable results within the framework of their study, McKinsey \& Company and the VDMA cluster the different business models into the five groups, based on identified patterns. Although very few companies fit perfectly into the definition of an archetype, they can assign each company to an archetype.

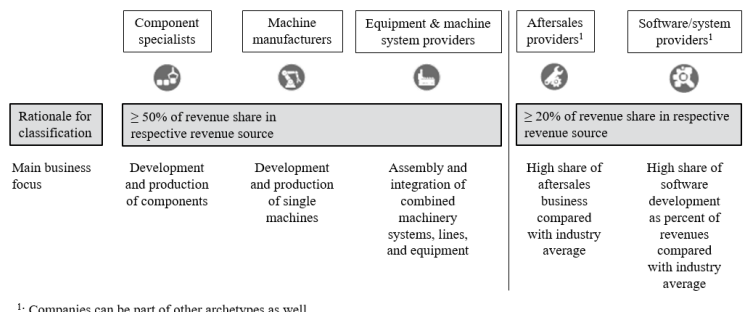

Figure 3 The 5 business archetypes across the European machinery industry

Source: Designed based on McKinsey \& Company and VDMA, 2016, p. 17

According to McKinsey \& Company and the VDMA (2016, p. 16) the net value added differs considerably between the different companies within the industry. Companies that develop and manufacture their products mainly from raw materials have a higher share of the value added $(\geq 70 \%$ ) than companies that focus mainly on assembly and procurement of the necessary components externally $(<40 \%)$. The value chain within the industry can be simplified by taking a closer look at the dynamics of the three following archetypes: components specialists, machine manufactures and equipment \& machine system providers. They are closely interconnected through the industry's value chain. Figure 4 provides a simplified description of the value chain using representative suppliers of the related business model archetypes.

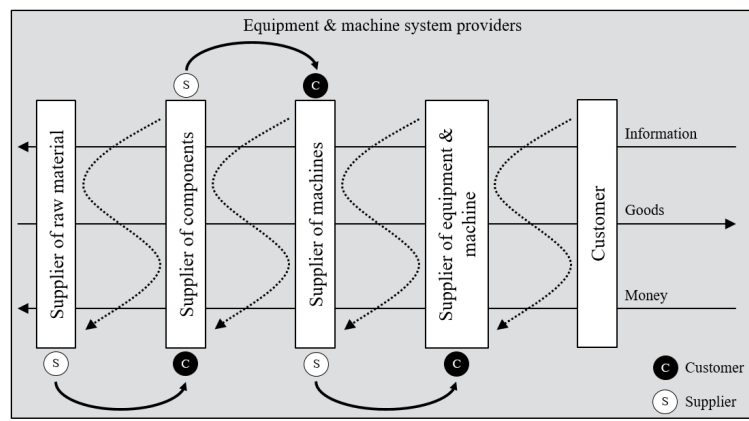

Figure 4 Simplified illustration of the value chain using the example of an equipment \& machine system provider Source: Designed based on IHK Nürnberg für Mittelfranken (ed.), 2014, p. 16

In this example, the company's internal orderto-payment process is not considered, but only the value creation of it within the industry sector. The value chain can be understood as a system of input flows (e.g. raw material), flows within the industry sector and output flows (e.g. customers). The flows within the industry sector can be described as a sequence of several order-topayment processes that take place in upstream and 
downstream companies (IHK Nürnberg für Mittelfranken (ed.), 2014, p. 16). The main actors of the simplified value chain are the suppliers of raw material, components, machines, equipment and machines as well as the customer. In the mutual business process, they exchange information and money for goods (see s-curve). Depending on the business relationship and direction, some companies switch the role as they act reciprocally as customers of an upstream partner and as suppliers of a downstream partner. It is not unusual that products do not only pass through the system in the form of a chain but are distributed to different actors in the form of a network (IHK Nürnberg für Mittelfranken (ed.), 2014, p. 17). Companies can thus act simultaneously as suppliers and customers of products and solutions. Due to the high complexity of products and services in this industry, the described distribution of products is essential in order to function as a holistic solution provider for the customers (IHK Nürnberg für Mittelfranken (ed.), 2014, p. 17).

As an example, the food processing and packing industry clearly illustrates (figure 5) the link of the different actors within its value chain. The figure shows the different industrial sectors within the various business model archetypes and their distribution of the products.

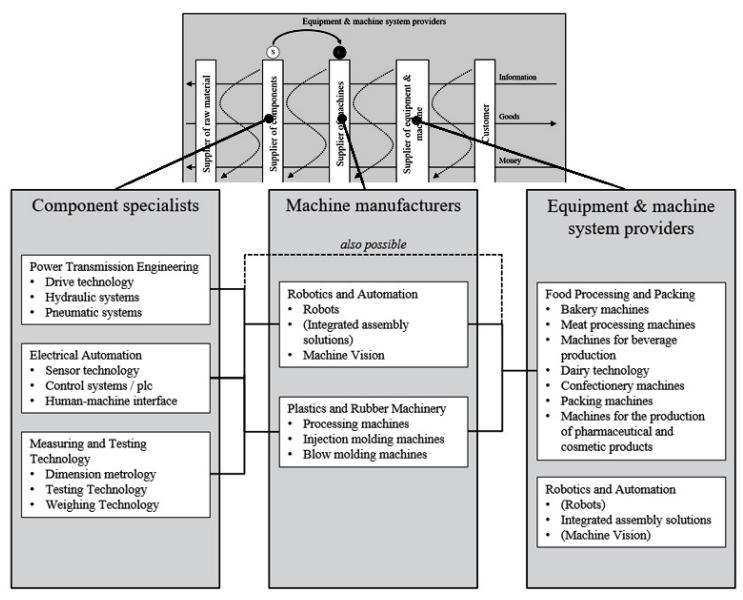

Figure 5 Representative illustration of the value chain, considering the various industrial sectors, exemplified by the food processing and packing industry

Source: Designed based on VDMA Antriebstechnik und Fluidtechnik (ed.), 2017; VDMA Mess- und Prüftechnik (ed.), 2019; VDMA Robotik + Automation (ed.), 2018; VDMA Fachverband Kunststoff und Gummima. (ed.), , 2019; VDMA Elektrische Automation (ed.), 2018; VDMA Future Business (ed.), 2020

Figure 5 shows common products of the different industry sectors (e.g. Power Transmission Engineering, Robotics and
Automation, Food Processing and Packing) within their respective business model archetype, including components specialists, machine manufacturers, and equipment and machine system providers. In addition, the value creation within the industry is simply presented, as individual components and products are built upon one another. The components specialists produce their components (e.g. drives, sensors and testing technology) and deliver these to the machine manufacturers and in some cases also directly to the equipment \& machine system providers. The machine manufacturers use their original equipment manufacturing (OEM) business to build machines (e.g. robots and process machines) based on the received components. Then, these manufacturers deliver the machines to the equipment suppliers. The machines are then used together with the components specialists' products to manufacture their integrated production solutions. This example illustrates that holistic solutions can only be realized by the linkage of different products (e.g. drives, sensors and testing technology, robots, process machines, etc.).

According to McKinsey \& Company and the VDMA (2016), it is not uncommon for companies to be active in aftersales and/or as a software provider in addition to their main archetype business (e.g. components specialists, machine manufacturers and equipment \& machine providers). Some companies use the sale of their original equipment as a catalyst to subsequently offer the profitable service business. Other companies offer their service business in addition to the equipment business, but only at the customer's request and not as the primary business.

The result and conclusion of the aforementioned study is similar to the archetypes study by McKinsey \& Company in 2018 (Altmeier, Bauer, Becker, \& Simon, 2019). They analysed 146 companies in Europe in the field of machinery and industrial automation sector. Altmeier et al. (2019) cluster the business models of market participants with similar patterns into 3 business model archetypes (1. OEM (Original Equipment Manufacturer) and system integrator; 2. Supplier; and 3. Software, platform, and application provider). Each archetype has its own characteristics and corresponding subcategories. In this context, they combine the OEMs with the system integrators within one cluster and do not consider the aftersales as a separate business 
model, as it is included in each of the 3 archetypes. Altmeier et al. (2019) distinguish OEMs and system integrators not based on their position within the value chain but based on standard machines (such as robots or milling machines) with limited customer-specific adaptions and customer-specific production equipment among the suppliers, who produce and deliver components either directly to the OEMs and system integrators for integration or into the independent aftermarket. The archetype of the software, platform, and application providers is pretty much the same as the software/system providers of the first study from McKinsey \& Company and the VDMA (2016). Altmeier et al. (2019) also point out that very few players fit perfectly into the definition of one archetype but can be assigned to an archetype or its subcategory, which is a comparable statement to the first study.

\subsection{Description of the four dimensions of the five business model archetypes}

As aforementioned, there are 5 business model archetypes (figure 3), which are a cluster of various business models of the companies within the industry. These archetypes have limited applicability within this context, therefore further analysis is required. In order to identify the correlation between "KPIs" (Section 2.3) and the individual elements of the business models, the business model archetypes must first be detailed (figure 6). For this purpose, a literature research was conducted using key questions. These questions are taken from the St. Gallen Business Model Navigator (Gassmann, Frankenberg, \& Csik, 2017, pp. 29-30) and serve as a template for determining the 4 dimensions of a business model, such as target customer, value proposition, value chain and revenue model.

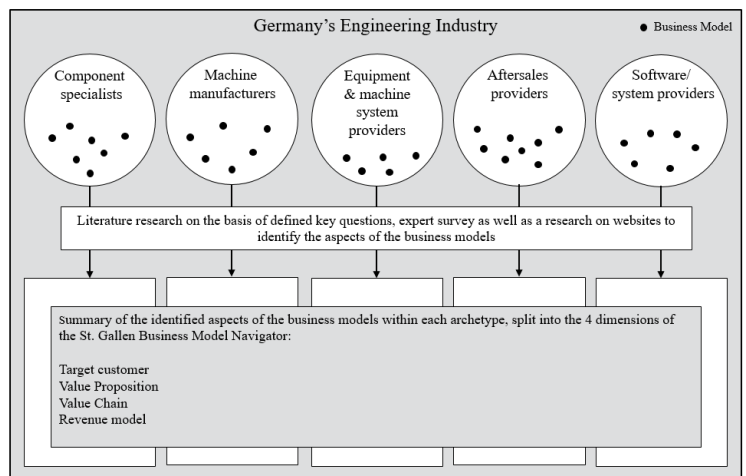

Figure 6 Procedure to identify the aspects of the clustered business models within the archetypes, using the St Gallen Business Model Navigator Source: The authors
The dimensions include target customer, value proposition and value chain that are determined via literature research. As mentioned, the available literature has only limited data on the revenue model. Therefore, an additional expert survey and research on the websites of representative companies were conducted. The survey is conducted with internal and external experts from various sectors of the German engineering industry, such as electrical automation, machine tools and manufacturing systems, robotics + automation, and large industrial plant manufacturing using a questionnaire. The overview of the respondents by archetype, company size and industry sector are presented in table 2 .

Table 2 Survey participants - Revenue model; Number of respondents by archetype, company size and industry sector

Number of respondents by archetype, company size, industry sector (multiple choice), $n=10$ participants

\begin{tabular}{|c|c|c|c|c|c|c|}
\hline$\frac{\sum_{0}^{\circ}}{\frac{0}{0}}$ & 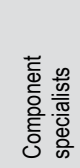 & 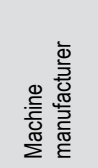 & 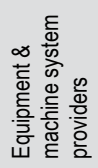 & \multicolumn{2}{|c|}{ 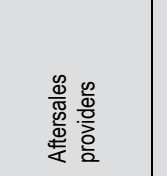 } & 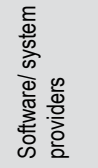 \\
\hline $\begin{array}{l}\dot{\mathscr{D}} \\
\dot{\mathscr{\Perp}}\end{array}$ & 7 & 5 & 6 & \multicolumn{2}{|l|}{10} & 9 \\
\hline 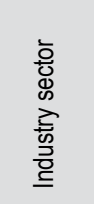 & 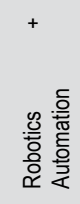 & 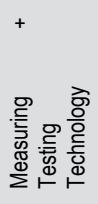 & 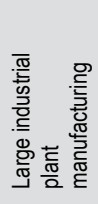 & 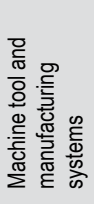 & 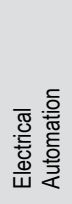 & 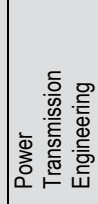 \\
\hline $\begin{array}{l}\dot{0} \\
\dot{0} \\
\propto\end{array}$ & 5 & 4 & 5 & 1 & 2 & 3 \\
\hline 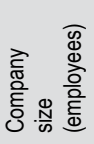 & $\frac{8}{\frac{8}{8}}$ & 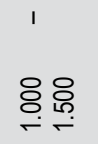 & 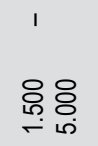 & $\begin{array}{l}1 \\
\text { 용ㅇㅇㅇ } \\
\text { 으 눈 }\end{array}$ & $\begin{array}{l}1 \\
808 \\
8 \\
8 \\
\text { 용 }\end{array}$ & $\begin{array}{l}1 \\
\circ 8 \\
8 \\
\circ\end{array}$ \\
\hline $\begin{array}{l}\dot{\otimes} \\
\ddot{\&}\end{array}$ & 1 & 1 & 4 & 2 & 1 & 1 \\
\hline
\end{tabular}

Overall, ten experts were asked to answer the questionnaire and their feedback is reflected in the description of the revenue model in the related archetype. The questionnaire does not consider the revenue made by the company within each archetype. It evaluates which opportunities the experts have selling or purchasing products and services. Table 3 shows the number of respondents by archetype and revenue model. 
Table 3 Number of respondents by archetype and revenue model

Number of respondents by archetype and revenue model (multiple choice), $\mathrm{n}=10$ participants

\begin{tabular}{|c|c|c|c|c|c|}
\hline $\begin{array}{l}\text { Archetype } \\
\text { Revenue } \\
\text { model }\end{array}$ & 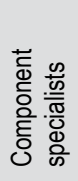 & 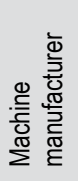 & 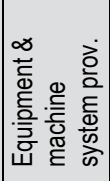 & 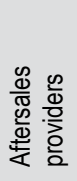 & 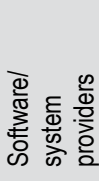 \\
\hline Selling & 7 & 5 & 6 & 10 & 9 \\
\hline Leasing & & 4 & & 3 & \\
\hline Renting & 4 & 4 & & 3 & \\
\hline Licensing & 3 & 4 & & 5 & 9 \\
\hline Pay-per-use & 3 & 4 & & & 3 \\
\hline $\begin{array}{l}\text { Subscription- } \\
\text { based }\end{array}$ & & 4 & & 1 & 5 \\
\hline Freemium & & & & & 2 \\
\hline $\begin{array}{l}\text { Interaction } \\
\text { platforms and } \\
\text { ecosystems }\end{array}$ & 2 & & & & 4 \\
\hline
\end{tabular}

The overview of the revenue models' description is presented in table 4.

Table 4 Description of the different revenue models

\begin{tabular}{l|l}
\hline $\begin{array}{l}\text { Selling (Rental } \\
\text { purchase/Financing) }\end{array}$ & $\begin{array}{l}\text { Retention of ownership of the } \\
\text { product/service for a single }\end{array}$
\end{tabular}
purchase/Financing) $\quad$ product/service for a single payment (also possible in instalments). The landlord has granted the tenant the right to purchase the rented object by unilateral declaration within a certain period. Within this period, a constant monthly amount is usually paid.

\begin{tabular}{l|l}
\hline Leasing & $\begin{array}{l}\text { In leasing, services or products are } \\
\text { rented to a certain extent, as } \\
\text { leasing is a transfer of use for } \\
\text { money on a temporary basis. } \\
\text { The lessee is liable for the failure } \\
\text { of the product and must carry out } \\
\text { repairs and maintain the object } \\
\text { himself. }\end{array}$ \\
\hline Renting & $\begin{array}{l}\text { Renting is similar to leasing, with } \\
\text { the main difference, that the lessor } \\
\text { is liable for the failure of the } \\
\text { product and must carry out repairs } \\
\text { and maintain the object (not the } \\
\text { tenant). }\end{array}$ \\
\hline Licensing & $\begin{array}{l}\text { The owner of intellectual property } \\
\text { (e.g. technology, process know- } \\
\text { how) can grant licenses to other } \\
\text { companies in exchange for } \\
\text { royalties to allow them to use this } \\
\text { property. A licensing model can } \\
\text { also be used to limit the } \\
\text { performance of components, } \\
\text { machines or equipment. }\end{array}$ \\
\hline $\begin{array}{l}\text { The use of a product or service is } \\
\text { measured, and a fee is charged to } \\
\text { customers each time they use the } \\
\text { service or product. The user has }\end{array}$ \\
\hline Pay-per-use (Selling of uptime \\
or output)
\end{tabular}

\begin{tabular}{l|l}
\hline & $\begin{array}{l}\text { no acquisition costs, no capital } \\
\text { commitment and no running costs. }\end{array}$ \\
\hline Subscription-based & $\begin{array}{l}\text { Subscription business models are } \\
\text { based on the idea of selling a } \\
\text { product or service in order to } \\
\text { receive monthly or annually } \\
\text { recurring subscription revenues. }\end{array}$ \\
\hline Freemium & $\begin{array}{l}\text { Freemium is a business model in } \\
\text { which the basic product is offered } \\
\text { for free, while the full product and } \\
\text { extensions are subject to a fee. }\end{array}$ \\
\hline $\begin{array}{l}\text { Interaction platforms and } \\
\text { ecosystems }\end{array}$ & $\begin{array}{l}\text { On interaction platforms, the } \\
\text { supplier connects multiple parties } \\
\text { and coordinates their interactions. } \\
\text { On ecosystems, companies can } \\
\text { facilitate the further development } \\
\text { of products and applications based } \\
\text { on their own product offering. }\end{array}$ \\
\hline \multicolumn{1}{c}{ Source: The authors }
\end{tabular}

The following sections include the four dimensions of each archetype (component specialists, machine manufacturers, equipment and machine system providers, aftersales providers, software/system providers), which are described based on the identified characteristics, such as literature research, website research and expert survey. The description of the respective dimension is not based on a single business model, but rather on a combination of characteristics of different business models of the examined industrial sectors.

\subsubsection{Four dimensions of the business model archetype: Component specialists}

This section presents the results of the research and the survey, which were used to determine the four dimensions of the component specialists' business model archetype. The development and manufacturing of components for industrial machines and equipment is the specialists' main business focus (McKinsey \& Company and VDMA, 2016, p. 17). The underlying research is based on sources of the industrial sectors, which can be assigned to the components specialists' archetype.

\section{Target customer}

- The machine manufacturers (section 2.2.2) and the equipment and machine system providers (section 2.2.3) (McKinsey \& Company and VDMA, 2016).

- OEMs with limited customer-specific adaptions and system integrators with customer-specific adaptions (Altmeier et al., 2019, p. 8).

- Strong focus on homeland markets with a production footprint linked to machine 
manufacturers (McKinsey \& Company and VDMA, 2016, p. 71).

- Additional industries such as automotive, shipbuilding and manufacturers of railway vehicles (VDMA Motoren und Systeme (ed.), 2019, p. 7).

- Key account management system for customer care is used in most cases, while focusing on premium segments (McKinsey \& Company and VDMA, 2016).

- Offering customized and machine-specific parts at online information and ordering platforms (24/7) (McKinsey \& Company and VDMA, 2016, p. 36).

\section{Value proposition}

- Innovative products and services with a distinctive customer orientation and product quality (McKinsey \& Company and VDMA, 2016; VDMA Antriebstechnik und Fluidtechnik (ed.), 2017; VDMA Elektrische Automation (ed.), 2018).

- Customized solutions (McKinsey \& Company and VDMA, 2016; IHK Nürnberg für Mittelfranken (ed.), 2014; CECIMO (ed.), 2011).

- Product range includes components from sectors such as drive technology, hydraulic and pneumatic systems, sensor technology, control systems, dimension metrology, internal combustion engines for industrial applications and precision tools such as cutting tools (VDMA Antriebstechnik und Fluidtechnik (ed.), 2017; VDMA Elektrische Automation (ed.), 2018; VDMA Mess- und Prüftechnik (ed.), 2019; VDMA Motoren und Systeme (ed.), 2019).

- Free services in the form of platforms and simulation tools (VDMA Antriebstechnik und Fluidtechnik (ed.), 2017, p. 15).

- Date and delivery reliability (IHK Nürnberg für Mittelfranken (ed.), 2014, p. 19).

- Compliance with the European regulation for health and safety (IHK Nürnberg für Mittelfranken (ed.), 2014).

- Availability of spare parts for durable machines over longer periods of time (IHK Nürnberg für Mittelfranken (ed.), 2014, p. 19).

\section{Value chain}

- Highly vertically integrated manufacturing process, which leads to a high share of net value added (McKinsey \& Company and VDMA, 2016; Altmeier et al., 2019; IHK Nürnberg für Mittelfranken (ed.), 2014).

- Long-term partnership with their customers and focus on the development of their own components (CECIMO (ed.), 2011; VDMA Antriebstechnik und Fluidtechnik (ed.), 2017).

\section{Revenue model}

- Most common: sale of components.

- Additional: renting, licensing, and pay-peruse models.

\subsubsection{Four dimensions of the business model archetype: Machine manufacturers}

This section covers the four dimensions of the machine manufacturers' business model archetype. The manufacturers' main business focus, according to McKinsey \& Company and the VDMA (2016, p. 17), is the development and manufacturing of single machines such as milling machines or mobile equipment for agricultural or constructional applications. This archetype also includes products that can be used directly by an integrator, such as robots, complete lasers with optics and beam guidance (e.g. for marking), complete process units and standalone tools (e.g. for labelling and dispensing applications). The underlying research is based on sources of the industrial sectors, which can be assigned to the archetype machine manufacturers.

\section{Target customer}

- Mainly high-priced products with limited diversification (McKinsey \& Company and VDMA, 2016, p. 72).

- Equipment \& machine system providers inside and outside the engineering industry (McKinsey \& Company and VDMA, 2016).

- Customers vary greatly --> end-users or actors within their own supply chain (CECIMO (ed.), 2011).

- Industries such as automotive, aerospace and aeronautics industry, medical technology, shipbuilding, manufacturers of railway vehicles, manufacturers of power generation and distribution equipment, agricultural machinery and construction equipment (CECIMO (ed.), 
2011; German Machine Tool Builders' Association (ed.), 2020; VDMA Landtechnik (ed.), 2020; McKinsey \& Company, 2016).

- Rental and leasing companies (McKinsey \& Company, 2016, p. 19).

\section{Value proposition}

- Innovative products and services with a distinctive customer orientation and a distinctive product quality (e.g. a high energy and resource efficiency) (German Machine Tool Builders' Association (ed.), 2020; VDMA Landtechnik (ed.), 2020; CECIMO (ed.), 2011).

- Differentiation of own products to differ from competition (CECIMO (ed.), 2011; McKinsey \& Company, 2016).

- Close partnership with customers to develop new and better solutions (CECIMO (ed.), 2011; McKinsey \& Company, 2016).

- Customer-oriented application solutions rather than standard machines (CECIMO (ed.), 2011, p. 22).

- Strong ability to respond to customer requirements and the flexibility to offer a wide range of solutions for their changing needs (CECIMO (ed.), 2011, p. 22).

- Intelligent solutions for fuel efficiency and $\mathrm{CO} 2$ reduction (VDMA Landtechnik (ed.), 2020; McKinsey \& Company, 2016).

- Compliance with EU Directives regarding health and safety standards (CECIMO (ed.), 2011; VDMA Landtechnik (ed.), 2020; McKinsey \& Company, 2016).

\section{Value chain}

- Medium depth of value added with lean manufacturing footprint and leverage supplier base, and a close linkage and cooperation with their suppliers (McKinsey \& Company and VDMA, 2016; CECIMO (ed.), 2011).

- Outstanding operational excellence in operational scale and low-cost production and sourcing (McKinsey \& Company and VDMA, 2016; CECIMO (ed.), 2011; McKinsey \& Company, 2016).

- Outsourcing of less strategic components and activities and focusing on core competences in developing and manufacturing of the equipment (CECIMO (ed.), 2011, p. 17).

\section{Revenue model}

- Most common: financing options such as rental purchasing, financing, leasing and renting are frequently offered by the companies (McKinsey \& Company, 2016), such as TRUMPF (TRUMPF Financial Services, 2020) or Heller (Gebr. Heller Maschinenfabrik $\mathrm{GmbH}, 2020 \mathrm{a}$, 2020b), which are suppliers of machine tools.

- Pay-per-use models (HELLER4Use) (Gebr. Heller Maschinenfabrik $\mathrm{GmbH}$, 2020a, 2020b).

- Pay according to the operating hours of the rented equipment (Liebherr-International Deutschland $\mathrm{GmbH}, 2020$ ).

- Subscription model, pay-per-use and licensing model, which include billing according to operating hours or number of uses and the option of ordering certain machine functions on demand (Mücke, 2019). Heidelberger, one of the biggest suppliers of printing machines globally, offers a pay-per-use model. Within this model the customer gets all components required for printing, such as the press system, software, consumables and service. In this case, the customer pays exclusively for the price per printed sheet agreed with Heidelberger (Heidelberger Druckmaschinen AG, 2020).

- Performance-related offerings and contracts, which are used by construction equipment manufacturers in the form of selling of uptime or output (e.g. material moved) (McKinsey \& Company, 2016, p. 46).

- Offering machinery in used condition (McKinsey \& Company, 2016; LiebherrInternational Deutschland GmbH, 2020; Gebr. Heller Maschinenfabrik $\mathrm{GmbH}$, 2020a, 2020b).

\subsubsection{Four dimensions of the business model archetype: Equipment and machine system providers}

The four dimensions of the equipment \& machine system provider business model archetype are determined in this section. Their main business focus is on the delivery of processing machinery equipment such as food and beverage, wood and textile. However, fully automated packaging lines, assembly lines and entire turnkey solutions such as power plants are also in their scope (McKinsey 
\& Company and VDMA, 2016, p. 17). The underlying research is based on sources of the industrial sectors, which can be assigned to the archetype machine manufacturers.

\section{Target customer}

- Focus only on one price segment and a few selected premium customer industries (McKinsey \& Company and VDMA, 2016; McKinsey \& Company and VDMA, 2014a, 2014b, 2014c, 2014d; VDMA Future Business (ed.), 2020).

- Customers come from the most diverse industries:

1. Metallurgical plants and rolling mills for the production and processing of steel, conventional (e.g. fossil-fuelled, gas, nuclear) and regenerative power plants, and plants for cement production (VDMA Large Industrial Plant Man. Group (ed.), 2020; PwC and VDMA (ed.), 2019).

2. Chemical plants, to produce plastics and fertilizers, and special chemicals, such as flame retardants, light stabilizers and food additives (PwC and VDMA (ed.), 2019, p. 20).

3. Pulp and paper plants, which produce graphic and hygiene paper (e.g. toilet and kitchen paper as well as tissues), and drinking water and sewage plants (VDMA Large Industrial Plant Man. Group (ed.), 2020).

4. Food and packaging machinery and textile machinery, with focus on food companies and manufacturer of pharmaceutical and cosmetic products (McKinsey \& Company and VDMA, 2014a, 2014b, 2014c, 2014d; VDMA Future Business (ed.), 2020).

- Intelligent, economical and integrated assembly and production solutions, which manage complex production sequences and a multitude of technical processes (e.g. joining, forming, handling, measuring and testing) (McKinsey \& Company and VDMA, 2014a, 2014b, 2014c, 2014d).

\section{Value proposition}

- Customer-orientation with distinctive quality tailored to individual customer requirements (McKinsey \& Company and VDMA, 2016).

- Design and delivery of equipment in close cooperation with customers (VDMA Large Industrial Plant Man. Group (ed.), 2020).

- Innovative and high-performance customer-specific complete solutions (McKinsey \& Company and VDMA, 2014a, 2014b, 2014c, 2014d).

- Qualitative and innovative large industrial plants with high productivity and energy efficiency, which aims to meet the environmental protection standards to significantly reduce their energy consumption and $\mathrm{CO} 2$ emissions (VDMA Large Industrial Plant Man. Group (ed.), 2020).

- Provision of low investment costs for short project processing times, as some customers focus on the operating costs of plants when making buying decisions (VDMA Large Industrial Plant Man. Group (ed.), 2020).

\section{Value chain}

- Highly horizontally integrated, with strong focus on technology while concentrating on assembly and integration of different machinery systems, lines, and equipment (McKinsey \& Company and VDMA, 2016).

- Comprehensive technical process expertise, to handle the entire necessary project and risk management, with aspects such as planning, designing and engineering of the plant (VDMA Future Business (ed.), 2020).

- Management of the supply chain management, with aspects such as production and procurement of the machinery and the facilities, and their delivery, assembly and commissioning (VDMA Large Industrial Plant Man. Group (ed.), 2020).

- Focus on a lean manufacturing footprint and leverage supplier base, with close relationship with their suppliers in terms of cooperation (McKinsey \& Company and VDMA, 2016).

\section{Revenue Model}

- Different financing packages for the customers, to allow them the option for long-term payments for their high investment costs (VDMA Large Industrial Plant Man. Group (ed.), 2020). 


\subsubsection{Four dimensions of the business model archetype: Aftersales providers}

This section describes the four dimensions of the aftersales providers' business model archetype, based on the identified characteristics of the research and the results of the questionnaire. In this study, the sales share of companies is not considered, since these only describe the affiliation to an archetype. As such, component specialists, machine manufacturers, and equipment and machine system providers are considered because they all offer different levels of aftersales (McKinsey \& Company and VDMA, 2016, p. 18). The underlying literature research is based on sources which were used for the dimension determination of the previous 3 archetypes (see section 2.2.1, 2.2.2 and 2.2.3).

\section{Target customer}

- The same customers as for the initial sale of components, machines or plants.

\section{Value proposition}

- Distinctly customer-centric with a close customer relationship (McKinsey \& Company and VDMA, 2016; McKinsey \& Company, 2016).

- Distinctive quality of products and service (McKinsey \& Company and VDMA, 2016).

- Focus on spare and wear parts, repairs, maintenance and refurbishment, which usually lead to reduction of the life cycle costs of the machine. Retrofits are also offered, in order to increase the efficiency and availability, whereas modernization can lead to solutions for more climate and environmental protection (McKinsey \& Company and VDMA, 2014a, 2014b, 2014c, 2014d; VDMA Large Industrial Plant Man. Group (ed.), 2020).

- Individual end-to-end solutions to support the customer in every phase of the product life cycle, from remote monitoring of operation, maintenance, repair to disposal (IHK Nürnberg für Mittelfranken (ed.), 2014, p. 25).

- Training for operating and maintenance personnel with different training levels (CECIMO (ed.), 2011).

- Online and 24/7 phone services to extend availability (McKinsey \& Company and VDMA，2014a，2014b，2014c，2014d;
IHK Nürnberg für Mittelfranken (ed.), 2014).

\section{Value chain}

- Extensive service network with qualified employees, optimized response time and spare parts logistics to provide optimum service to the customers (McKinsey \& Company and VDMA, 2014a, 2014b, 2014c, 2014d).

- Partnerships with aftersales providers inside and outside the industry, and cooperation with specialized service providers or mobile service stations (McKinsey \& Company and VDMA, 2014a, 2014b, 2014c, 2014d; VDMA Large Industrial Plant Man. Group (ed.), 2020).

- Aftersales and service offerings are often used as a differentiation feature against competitors (McKinsey \& Company and VDMA, 2014a, 2014b, 2014c, 2014d).

\section{Revenue model}

- Most common: selling-based revenue model.

- Additional: leasing, rental, licensing and subscription-based revenue models.

\subsubsection{Four dimensions of the business model archetype: Software and system providers}

The following section covers the identified characteristics of the research and the results of the questionnaire regarding software and system providers of business model archetype. Similar to the description of aftersales providers, the component specialists, machine manufacturers, and equipment \& machine system providers are considered because they all offer software (McKinsey \& Company and VDMA, 2016, p. 18). The underlying literature research is based on sources, which were used for the dimension that determined the 3 archetypes before (see Sections 2.2.1, 2.2.2 and 2.2.3).

\section{Target customer}

- The same customers as for the initial sale of the components, machines or plants.

\section{Value proposition}

- Strong customer orientation (McKinsey \& Company and VDMA, 2016).

- Focus on the homeland market with the attempt to cover all price segments 
(McKinsey \& Company and VDMA, 2016, p. 75).

- One way to create additional value is the collection and analysis of all sorts of machine-related data:

1. Maintenance manager that maps, manages and monitors the installed sensors of a user, and a tool which enables the visualization of measured values and parameters as well as their transfer into the condition monitoring, in order to improve the machine's availability and productivity (Smart Service Suite) (SICK AG, 2020).

2. Machine networking, fleet management and remote maintenance as well as software solutions for the optimized application of fertilizers and crop protection agents (CLAAS KGaA $\mathrm{mbH}$, 2020).

3. Customized solutions for monitoring and maintenance as well as increasing the efficiency and profitability of systems and machines, innovative services such as drone inspections for visual inspections of plants and machines, and the analysis of the collected data (Thyssenkrupp Industrial Solutions AG, 2020).

\section{Value chain}

- Highly qualified workforce with digital skills, consisting of specialists such as IT managers, programmers and experts for artificial intelligence (VDMA Large Industrial Plant Man. Group (ed.), 2020, p. 19).

- Experts in software design, who develop app-like products and advanced analytics (McKinsey \& Company and VDMA, 2016; Altmeier et al., 2019).

- Get to know the end customer better and tailor machines and solutions using collected data (McKinsey \& Company, 2016, p. 48; Haziri, Chovancova, \& Fetahu, 2019).

- Data is also used for increased performance, reduction of downtime, and optimization of maintenance, which leads to refining the machine design and functionality long-term (McKinsey \& Company, 2016).

- Cooperation with software suppliers to increase the own level of digitization
(McKinsey \& Company and VDMA, 2016, p. 52).

\section{Revenue model}

- Most common: selling and licensing models

- Common: subscription-based model and interaction platforms and ecosystems

- Additional: pay-per-use and freemium models

\subsection{Success patterns of the German engineering industry}

The following section identifies success patterns of the German engineering industry characterized by recurring factors and behavioural patterns. These success patterns are indicators, which may help affected companies achieve sustainable profitable growth and competitiveness within this industry. The basis of this investigation includes the two success pattern analyses of Eisenhut and Lässig (2013), and McKinsey \& Company and VDMA (2014).

\subsubsection{Success patterns according to Eisenhut and Lässig (2013)}

Eisenhut and Lässig (2013) analysed publicly available data of 50 different German engineering companies in order to identify recurring success patterns. Thereby, they realized that these patterns can be transferred to other companies and help them with a long-term presence on the market despite changing conditions. To be considered as a successful company - a champion - in their analysis, a company must be above the median in the three key financial dimensions: sales growth, EBIT margin, equity ratio - segment adjusted. Additionally, one of the three dimensions has to be in the first quartile, at a minimum. The analysed companies are from sectors such as materials handling and logistics technology, robotics, woodworking, printing \& paper equipment and supplies, pulp and paper machinery, textile machines, packaging machines, machine tools, and manufacturing systems. Through Eisenhut and Lässig's (2013) analysis, they identified a total of 15 success patterns of champions, which they categorized into the three design fields: business model, value-added system and financial basis. Table 5 below provides an overview about the champions' five success patterns in the design field: business model. It explains the characteristics of the individual pattern within the champion's business model. 
Table 5 Definition of the five success patterns of the design field: business model

\begin{tabular}{|c|c|c|}
\hline $\begin{array}{l}\text { Design } \\
\text { field }\end{array}$ & $\begin{array}{l}\text { Success } \\
\text { Pattern } \\
\end{array}$ & Definition \\
\hline \multirow{5}{*}{ 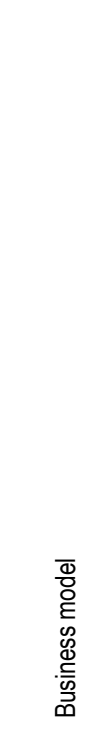 } & $\begin{array}{l}\text { Company } \\
\text { growth }\end{array}$ & $\begin{array}{l}\text { The champion's growth is moderate } \\
\text { and mostly organic. Based on the } \\
\text { champion's market knowledge, } \\
\text { products are developed specifically to } \\
\text { address new markets and customers. }\end{array}$ \\
\hline & $\begin{array}{l}\text { Innovation } \\
\text { leader }\end{array}$ & $\begin{array}{l}\text { The champion has the innovation } \\
\text { leadership in its niche, which ensures } \\
\text { its product positioning. }\end{array}$ \\
\hline & $\begin{array}{l}\text { Product } \\
\text { positioning }\end{array}$ & $\begin{array}{l}\text { The competition in the niche is } \\
\text { manageable and thus leads to a price } \\
\text { determination by supply and not by } \\
\text { demand. Building on this, tailor-made } \\
\text { premium products can be sold at } \\
\text { premium prices. }\end{array}$ \\
\hline & $\begin{array}{l}\text { Global } \\
\text { market } \\
\text { coverage } \\
\text { with locally } \\
\text { adapted } \\
\text { structures } \\
\end{array}$ & $\begin{array}{l}\text { The champion operates with a few } \\
\text { core locations and is supplemented } \\
\text { by local presence for sales and } \\
\text { service. }\end{array}$ \\
\hline & $\begin{array}{l}\text { Added value } \\
\text { of production }\end{array}$ & $\begin{array}{l}\text { The champion's production is } \\
\text { focused at a few domestic locations } \\
\text { with medium depth of value added. }\end{array}$ \\
\hline
\end{tabular}

Based on their analysis, Eisenhut and Lässig (2013, p. 48) conclude that the successful implementation of the five success patterns within the champion's business model plays a more decisive role for its success than its operational management. In other words, a dysfunctional business model does not lead to long-term success through operational management.

The next table shows the six identified success patterns of champions within the design field: value-added system. The value-added system consists mainly of functions and processes within the company.

Table 6 Definition of the six success patterns of the design field: value-added system

\begin{tabular}{|c|c|c|}
\hline $\begin{array}{l}\text { Design } \\
\text { field }\end{array}$ & $\begin{array}{l}\text { Success } \\
\text { Pattern }\end{array}$ & Definition \\
\hline & $\begin{array}{l}\text { Performance- } \\
\text { oriented } \\
\text { organization } \\
\text { with } \\
\text { continuous } \\
\text { leadership }\end{array}$ & $\begin{array}{l}\text { The champion's management } \\
\text { usually has been with the company } \\
\text { for years, in some cases decades. } \\
\text { Consequently, they have a wealth of } \\
\text { experience within the company and } \\
\text { the industry. This continuity is } \\
\text { significant, because it can lead to } \\
\text { more trust on the market, with } \\
\text { customers and with the own } \\
\text { employees. }\end{array}$ \\
\hline 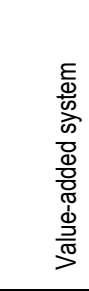 & $\begin{array}{l}\text { Optimized } \\
\text { R\&D allocation }\end{array}$ & $\begin{array}{l}\text { The champion controls all } \\
\text { development activities on a long- } \\
\text { term and continuous basis. Priorities } \\
\text { and goals for future products are } \\
\text { clearly defined and controlled for the } \\
\text { long term. The champion pays } \\
\text { attention to a balanced relationship } \\
\text { between customer-specific and } \\
\text { customer-neutral developments and }\end{array}$ \\
\hline
\end{tabular}

\begin{tabular}{l|l|l}
\hline & $\begin{array}{l}\text { invests a significant and stable share } \\
\text { of sales to these developments. }\end{array}$ \\
\cline { 2 - 3 } $\begin{array}{l}\text { Integrated } \\
\text { supplier } \\
\text { network }\end{array}$ & $\begin{array}{l}\text { The suppliers are intensively } \\
\text { integrated in the value creation of the } \\
\text { champion. This is reflected by the } \\
\text { integration into the operative } \\
\text { production process of the champion } \\
\text { and the usage of the suppliers' } \\
\text { expertise and skills for the } \\
\text { champion's own innovation and } \\
\text { development processes. }\end{array}$ \\
\cline { 2 - 3 } $\begin{array}{l}\text { Efficient } \\
\text { processes in } \\
\text { logistic and } \\
\text { production }\end{array}$ & $\begin{array}{l}\text { The champions' manufacturing is } \\
\text { highly automated by means of } \\
\text { efficient production and inventory } \\
\text { planning. They have lean production } \\
\text { lines with optimized lead times and } \\
\text { processes, which lead to an } \\
\text { optimized use of personnel. }\end{array}$ \\
\cline { 2 - 3 } $\begin{array}{l}\text { Intelligent } \\
\text { sales } \\
\text { management }\end{array}$ & $\begin{array}{l}\text { Champions open new markets and } \\
\text { businesses through a cross- } \\
\text { functional interaction of marketing, } \\
\text { product management and sales. For } \\
\text { this purpose, target customers are } \\
\text { identified, products are developed to } \\
\text { series-production readiness and } \\
\text { subsequently customers are visited. } \\
\text { The champions provide optimum } \\
\text { day-to-day support for their existing } \\
\text { customers in terms of new machines } \\
\text { and service. The champion } \\
\text { consistently manages the order } \\
\text { situation to ensure high transparency } \\
\text { of all leads and potential orders. The } \\
\text { order situation is the basis for } \\
\text { measuring and controlling sales } \\
\text { performance. }\end{array}$ \\
\hline After market & $\begin{array}{l}\text { The champion has a stable } \\
\text { customer-supplier relationship } \\
\text { throughout the life cycle of the } \\
\text { machine. On this basis, service for } \\
\text { spare parts, repairs and } \\
\text { maintenance is offered. }\end{array}$ \\
\hline
\end{tabular}

Source: Designed based on Eisenhut \& Lässig, 2013, pp. 48-56

The final design field - financial basis consists of four success patterns and is presented in Table 7. These patterns mainly focus on financial aspects.

Table 7 Definition of the four success patterns of the design field: financial basis

\begin{tabular}{|c|c|c|}
\hline $\begin{array}{l}\text { Design } \\
\text { field }\end{array}$ & $\begin{array}{l}\text { Success } \\
\text { Pattern }\end{array}$ & Definition \\
\hline \multirow{3}{*}{ 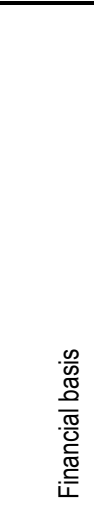 } & $\begin{array}{l}\text { Liquidity } \\
\text { management }\end{array}$ & $\begin{array}{l}\text { Although the champion is result- } \\
\text { oriented, cash flow is given } \\
\text { considerable attention in the core } \\
\text { functions of the company, such as } \\
\text { accounting, controlling, sales and } \\
\text { technical departments. }\end{array}$ \\
\hline & $\begin{array}{l}\text { Balance } \\
\text { sheet } \\
\text { structure }\end{array}$ & $\begin{array}{l}\text { The champions use their long-term } \\
\text { assets optimally, keep the share of } \\
\text { outside capital as low as possible } \\
\text { and use outside financing from } \\
\text { suppliers and customers actively for } \\
\text { their own business activities. They } \\
\text { define exactly which and how many } \\
\text { assets they really need. }\end{array}$ \\
\hline & $\begin{array}{l}\text { Investment } \\
\text { strategy }\end{array}$ & $\begin{array}{l}\text { The champion makes long-term, } \\
\text { continuous investments in product }\end{array}$ \\
\hline
\end{tabular}




\begin{tabular}{l|l|l}
\hline \multirow{2}{*}{$\begin{array}{l}\text { focused on } \\
\text { continuity }\end{array}$} & $\begin{array}{l}\text { development and production } \\
\text { technology, and coordinates these } \\
\text { investments with the innovation } \\
\text { cycles of the industry. }\end{array}$ \\
\cline { 2 - 3 } $\begin{array}{l}\text { Risk } \\
\text { management }\end{array}$ & $\begin{array}{l}\text { The champion operates a holistic risk } \\
\text { management as a cross-sectional } \\
\text { task in all important areas, such as } \\
\text { product development and positioning, } \\
\text { company growth, cash-management, } \\
\text { and sales. }\end{array}$ \\
\hline
\end{tabular}

\subsubsection{Success patterns according McKinsey \& Company and VDMA (2014)}

McKinsey \& Company and VDMA (2014) used a different approach to identify the success patterns of the German engineering industry. 333 companies from all sectors of the engineering industry were examined and partly interviewed within the framework of a comprehensive survey. These companies represent all company-size classes as well as different ownership and management structures. The two evaluation criteria for the company's success are sales growth and the profitability of the company as measured by EBIT. A company is considered successful within their analysis, if its sales growth or profitability exceeds the respective industry averages in at least one of the two financial dimensions. Based on the industry averages of the two financial key figures, a total of 10 success patterns have been identified (Table 8), with diverse characteristics in sales growth and profitability.

Table 8 Definition of the 10 success patterns of the German engineering industry

\begin{tabular}{|c|c|}
\hline Success Pattern & Definition \\
\hline $\begin{array}{l}\text { Company size in terms } \\
\text { of sales }\end{array}$ & $\begin{array}{l}\text { Companies of increasing size (sales) are } \\
\text { gradually becoming more profitable } \\
\text { through standardization and economies } \\
\text { of scale. The economies of scale play a } \\
\text { particularly important role on the cost } \\
\text { side. Savings result from improved } \\
\text { negotiating positions with suppliers as } \\
\text { purchase quantity and the number of } \\
\text { standardized parts increases. }\end{array}$ \\
\hline Internationalization & $\begin{array}{l}\text { Companies with international } \\
\text { manufacturing have cost advantages } \\
\text { over companies without and are } \\
\text { therefore more profitable and grow } \\
\text { faster. This is mainly shown by the } \\
\text { proximity to the customers in connection } \\
\text { with lower logistics costs as well as wage } \\
\text { and salary structures. Local purchasing } \\
\text { and on-site service also contribute to a } \\
\text { better result. }\end{array}$ \\
\hline Operational excellence & $\begin{array}{l}\text { Companies with best values in all three } \\
\text { key operating figures are more profitable } \\
\text { and show higher sales growth. These } \\
\text { operations figures include delivery }\end{array}$ \\
\hline
\end{tabular}

\begin{tabular}{l|l}
\hline & $\begin{array}{l}\text { reliability, the number of customer } \\
\text { complaints, as indicators for process and } \\
\text { product quality, and the ratio of selling } \\
\text { and administrative expenses to sales, as } \\
\text { an indicator of efficiency. }\end{array}$ \\
\hline Stringency in the & $\begin{array}{l}\text { Companies that focus on their core } \\
\text { business perform better in terms of } \\
\text { profitability and growth. They } \\
\text { consistently focus their structures and } \\
\text { processes on their core business. This } \\
\text { stringency on their business model can } \\
\text { manifest itself in different dimensions, } \\
\text { such as in the offer, and also in } \\
\text { processes. When accepting orders, clear } \\
\text { lines are defined in order to allocate } \\
\text { resources to the most promising } \\
\text { projects. }\end{array}$ \\
\hline Companies which are innovation leaders \\
within their branch are more profitable \\
and show higher sales growth. \\
Innovation often supports a clear brand \\
positioning and thus differentiation from \\
competitors. This allows a price premium \\
and can lead to higher margins. \\
Innovation takes place not only in \\
products and technologies, but also in \\
processes and applications.
\end{tabular}

Source: Designed based on McKinsey \& Company and VDMA, 2014a, 2014b, 2014c, 2014d

\subsection{Key performance indicators of the success patterns}

In this section, KPIs are determined based on the success patterns described previously. This determination is implemented in different ways for the success patterns of Eisenhut and Lässig (2013), and McKinsey \& Company and VDMA 
(2014). Based on the success patterns of Eisenhut and Lässig (2013) in Tables 5 to 7, KPIs are identified in two steps. First, the success patterns are coded by the champions' characteristics in order to focus their description on specific core elements (Table 9). Then, a literature research is performed based on the identified characteristics to derive the KPIs.

In the case of the success patterns of McKinsey \& Company and VDMA (2014) in table 8 , the KPIs can be described directly. Since they initially identified the majority of the KPIs in their analysis, this serves as the foundation of their success patterns.

\subsubsection{KPIs based on success patterns according to Eisenhut and Lässig (2013)}

Table 9 shows the champions' characteristics, which represent Eisenhut and Lässig's (2013) coded success patterns.

Table 9 Success patterns according to Eisenhut and Lässig (2013) coded by the champions' characteristics

\begin{tabular}{|c|c|}
\hline $\begin{array}{l}\text { Success Pattern } \\
\text { according Eisenhut } \\
\text { and Lässig (2013) }\end{array}$ & Champions' characteristics \\
\hline Company growth & - Moderate and mostly organic \\
\hline Innovation leader & - Innovation leadership \\
\hline Product positioning & - $\quad$ Premium prices \\
\hline $\begin{array}{l}\text { Global market } \\
\text { coverage with } \\
\text { locally adapted } \\
\text { structures }\end{array}$ & $\begin{array}{ll}\text { Few core locations } \\
\quad \text { Local presence for sales and service }\end{array}$ \\
\hline $\begin{array}{l}\text { Added value of } \\
\text { production }\end{array}$ & - Medium depth of value added \\
\hline $\begin{array}{l}\text { Performance- } \\
\text { oriented } \\
\text { organization with } \\
\text { continuous } \\
\text { leadership }\end{array}$ & $\begin{array}{l}\text { - Performance oriented organization } \\
\text { - Continuous leadership of management }\end{array}$ \\
\hline $\begin{array}{l}\text { Optimized R\&D } \\
\text { allocation }\end{array}$ & $\begin{array}{l}\text { - Long-term and continuous development } \\
\text { activities } \\
\text { - Balanced ratio between customer- } \\
\text { specific and customer-neutral } \\
\text { developments } \\
\text { - Significant and stable investments in } \\
\text { development activities }\end{array}$ \\
\hline $\begin{array}{l}\text { Integrated supplier } \\
\text { network }\end{array}$ & $\begin{array}{l}\text { - Suppliers are intensively integrated in } \\
\text { the value creation }\end{array}$ \\
\hline $\begin{array}{l}\text { Efficient processes } \\
\text { in logistic and } \\
\text { production }\end{array}$ & $\begin{array}{l}\text { - Lean and efficient production and } \\
\text { inventory planning }\end{array}$ \\
\hline $\begin{array}{l}\text { Intelligent sales } \\
\text { management }\end{array}$ & $\begin{array}{l}\text { - Cross-functional interaction of } \\
\text { marketing, product management and } \\
\text { sales for new markets and customers } \\
\text { - Optimum day-to-day support for existing } \\
\text { customers }\end{array}$ \\
\hline Aftermarket services & $\begin{array}{l}\text { Stable customer-supplier relationship } \\
\text { throughout the life cycle of the } \\
\text { machine }\end{array}$ \\
\hline $\begin{array}{l}\text { Liquidity } \\
\text { management }\end{array}$ & $\begin{array}{l}\text { - Cash flow attention in the core functions } \\
\text { of the company }\end{array}$ \\
\hline $\begin{array}{l}\text { Balance sheet } \\
\text { structure }\end{array}$ & $\begin{array}{l}\text { - The share of outside capital as low as } \\
\text { possible }\end{array}$ \\
\hline
\end{tabular}

\begin{tabular}{l|lc}
\hline $\begin{array}{l}\text { Investment strategy } \\
\text { focused on } \\
\text { continuity }\end{array}$ & - $\begin{array}{l}\text { Long-term, continuous investments in } \\
\text { product development and production } \\
\text { technology }\end{array}$ \\
\hline Risk management & - & Holistic risk management \\
\hline \multicolumn{2}{c}{ Source: the authors }
\end{tabular}

The champions' characteristics are used as the baseline for identifying KPIs. In the following section, a literature review is conducted to clarify the ambiguities of these characteristics and to identify the KPI's necessary details. At the end of this study, all results are summarized in Table 10.

\section{Company growth}

Company growth is determined by quantitative or qualitative methods, metrics and dimensions (e.g. sales, employees or others), measurement and calculation (e.g. absolute or relative) and the period under consideration (Schweiger, 2012, p. 35). Organic company growth refers to growth from the company's own resources and through internal value creation processes. The derived KPI considers the annual organic sales growth of the company, as sales is one of the most used company growth indicators (Delmar, 1997, p. 201).

\section{Innovation leader}

Innovation leadership refers to the fact that a company is a leader in its industry in the development and sales of innovative products or processes. Saunila (2017, pp. 3-4) identifies four types of corporate innovation performance measurements: inputs, process, outputs and outcomes. According to Janssen, Moeller and Schlaefke (2011, p. 112) output metrics relate to R\&D activities and measure the number of submitted, pending and approved patents per year, the share of new products in the product range, the number of new products per Euro spent on R\&D and the number of new products per employee in terms of R\&D. Outcome metrics are related to the success in the market and measure revenue, profit, market share, and customer satisfaction of the new products (Janssen \& Möller, 2011, p. 99). Absolute outcome metrics measure the revenue growth and market share growth based on new products. Relative outcome metrics measure sales of new products/R\&D per employee or annual sales/R\&D budget. Anthony (2013) highlights the Return on Innovation Investment (ROII) as a reasonable performance measure, as it evaluates a company's effectiveness in investing in new products. ROII is calculated by dividing the profit generated from the 
innovation through the cumulative investment required to create it.

\section{Product positioning}

The success pattern product positioning is coded by premium prices. Hinterhuber and Liozu (2018, p. 301) describe premium pricing as a strategy, which results in prices that are high in relation to the price level of competitors and customers. In $\mathrm{B} 2 \mathrm{~B}$, the pricing strategy focuses on the quantification of value, to shows that the price is below the customer's quantified value proposition. The derived KPI is premium price.

\section{Global market coverage with locally adapted structures}

A global market coverage with locally adapted structures is defined by few core locations with local presence for sales and service. This leads to a KPI, which measures the number of core sites as well as local sales and service sites.

\section{Added value of production}

The KPI for the medium depth of value added measures the level of the company's value added. A company's value added refers to the periodic value by which the company's output is added to the input received from other organizations to produce the output that is recognized as the company's total output (Känel, 2018, p. 132).

\section{Performance-oriented continuous leadership}

\section{organization}

with

Two KPIs are used to describe this success pattern. These include the measurement of the management's length of service and the performance of the company. Bausch, Buske and Hagemeier (2011, pp. 359-360) use accounting and finance figures to measure the internal and external performance of a company. In doing so, they refer to values related to the past. Here, the invested capital or assets must be compared with the earnings figures, which were generated by the invested capital or assets. Bausch et al. (2011, p. 373) highlight the Economic Value Added (EVA) method as a dominant key figure to measure the company's performance. EVA is usually used if the performance of an investment is measured on an annual basis. In this case, the EVA calculation answers the question of whether a project generates positive cash flows that exceed the return required by the investors (Gitman \& Zutter, 2012, p. 400).

\section{Optimized R\&D allocation}

The optimized R\&D allocation success pattern is described using three KPIs. First, the annual R\&D investment based on sales is determined in order to measure the company's significant and stable investments in development activities. The second KPI is the company's annual R\&D activity costs. The main cost driver for a company's internal $\mathrm{R} \& \mathrm{D}$ activities is usually personnel and equipment costs, which can be measured by this KPI (Janssen et al. 2011, p. 111). Finally, the ratio between customer-specific and customer-neutral developments is measured through the cost allocation of each development.

\section{Integrated supplier network}

Continuous supplier evaluation as part of the company's supplier management is the key to ensure supplier quality and to enable cooperation (Janker, 2008). Janker (2008, pp. 87-96) classifies the following eight main criteria for supplier evaluation, which define the KPIs of this success pattern: quantity output, quality performance, logistics service, remuneration, service, information and communication services, innovation performance and environmental performance.

\section{Efficient processes in logistic and production}

Dombrowski and Mielke (2015, p. 19) describe a holistic production system, which is a companyspecific version of a production system with elements of lean production. It is based on the Toyota Production System, as the origin of lean production. This system is described in VDI (Verein Deutscher Ingenieure) as a companyspecific and methodical set of guidelines. The guidelines consist of the following eight design principles: avoidance of waste, continuous improvement process, standardization, zero-error principle, flow principle, pull principle, employee orientation and goal-oriented leadership and visual management. It also includes a wide range of possible methods for each design principle (Dombrowski \& Mielke, 2015, p. 29).

\section{Intelligent sales management}

The four dimensions of sales excellence are strategy, organization, controlling and personnel (Pufahl, 2019). According to Pufahl (2019), a well-positioned organization is the key for positive business development, since employees are the most valuable capital of sales and the organizational framework is crucial for efficient 
market cultivation. In addition to the KPIs sales, incoming orders and customer satisfaction, the contribution margin, sales volumes and customer lifetime value play a central role in sales controlling (Pufahl, 2019). The Customer Lifetime Value (CLV) is the contribution of a customer, measured as the cash flow generated by the latter during the entire business relationship (Pufahl, 2019).

\section{Aftermarket service}

The success of a company's after sales and service is measured by the share of aftersales in total sales KPI.

\section{Liquidity management}

Cash flow is the financial surplus of payments received in the course of a company's business operations over payments made in the same accounting period. It is used, among other things, to assess the earnings and, above all, the selffinancing capacity of a company (Känel, 2018, p. 165). Monitoring and control of cash flow across all core functions of the company is the key to successful liquidity management. Cash flow synchronization is one key aspect in this context, highlighted by Arnold (2013, p. 523), as it describes the management of reducing the level of cash balances needed by scheduling the in- and outflows.

\section{Balance sheet structure}

A stable balance sheet structure is part of the solid foundation of a successful company (Eisenhut \& Lässig, 2013, p. 58). This makes a company comparatively independent of external investors and enables decisions to be made that are primarily oriented towards the company's own interests. According to Eisenhut and Lässig (2013, pp. 58-59), the return on equity (ROE) is a key metric that can be used as a KPI for this purpose. Return on equity measures the income-generating return on the equity that is effective in the business operations of a company on average over one year (Känel, 2018, p. 147).

\section{Investment strategy focused on continuity}

Jacobs (2019, p. 51) describes investment strategy, which is aligned with the industry's innovation cycles, as a necessity for companies. By identifying new technologies at an early stage and the resulting newly developed products, companies ensure innovation success and competitiveness. Ansoff, Kipley, Lewis, Helm-
Stevens and Ansoff (2019, pp. 131-134) address this need by the demand technology lifecycle. In this case, the product lifecycle is defined as a section of a superordinate technology lifecycle. The driving force of technology of this cycle illustrates that products lose their competitiveness; hence developments and innovations are unavoidable.

Fischer, Himme and Albers (2007) investigated the company's impact of the timing of the market entry based on the product lifecycle in the area of pharmaceutical product markets. They distinguish between the pioneer, the early follower and the late follower. The pioneer is the first to enter the market, closely followed by the early follower, but before the take-off of the product. The take-off is understood as the point in time of the first major increase in sales, when the market moves from the slowly growing launch phase to the growth phase. The late follower enters the market well after the take-off of the product. No clear correlation between the sequence of entry and the success of the different companies could be found within the study. Since the success of a company in the examined context refers to the sales of products, this success pattern is described based on the KPI revenue growth based on new products.

\section{Risk management}

Risk management in a corporate context can be described as the systematic analysis, evaluation, treatment and control of corporate risks (Brauweiler, 2019, p. 1). From the company's point of view, alongside the business necessity of identifying and avoiding risks, there are also legal requirements and regulations that the company must comply with (e.g. EU law, German Stock Corporation Act) (Brauweiler, 2019, p. 5). Brauweiler (2019) proposes a risk management system on company level, which identifies each significant risk and defines the associated monitoring and control procedures. The basis is a suitable reporting system with regular and ad-hoc reports. Risks are systematically recorded, presented and prioritized (in terms of probability and impact). Risk control comprises all necessary activities to eliminate or minimize the identified risks.

Table 10 summarizes the identified KPIs, the champions' underlying characteristics and the initial success patterns. 
Table 10 Success patterns according to Eisenhut and Lässig (2013) coded by the champions' characteristics and

\begin{tabular}{|c|c|c|}
\hline $\begin{array}{l}\text { Success Pattern } \\
\text { according Eisenhut } \\
\text { and Lässig (2013) }\end{array}$ & $\begin{array}{l}\text { Champions' } \\
\text { characteristics }\end{array}$ & KPls \\
\hline Company growth & $\begin{array}{l}\text { Moderate and } \\
\text { mostly organic }\end{array}$ & $\begin{array}{cc}\text { Annual organic } \\
\text { sales growth }\end{array}$ \\
\hline Innovation leader & $\begin{array}{l}\text { Innovation } \\
\text { leadership }\end{array}$ & $\begin{array}{l}\text { - } \\
\text { pumber of patents } \\
\text { per year } \\
\text { (submitted, } \\
\text { pending and } \\
\text { approved) } \\
\text { Share of new } \\
\text { products in the } \\
\text { product range } \\
\text { Number of new } \\
\text { products per Euro } \\
\text { spent on R\&D } \\
\text { Number of new } \\
\text { products per R\&D } \\
\text { employee } \\
\text { Revenue share of } \\
\text { new products } \\
\text { Profit share of new } \\
\text { products } \\
\text { Market share of new } \\
\text { products } \\
\text { Customer } \\
\text { satisfaction of new } \\
\text { products } \\
\text { Revenue growth } \\
\text { based on new } \\
\text { products } \\
\text { Market share growth } \\
\text { based on new } \\
\text { products } \\
\text { Sales of new } \\
\text { products per R\&D } \\
\text { employee } \\
\text { Return on } \\
\text { Innovation } \\
\text { Investment (ROII) } \\
\text { - }\end{array}$ \\
\hline Product positioning & - $\quad$ Premium prices & - $\quad$ Premium prices \\
\hline $\begin{array}{l}\text { Global market } \\
\text { coverage with } \\
\text { locally adapted } \\
\text { structures }\end{array}$ & $\begin{array}{ll}\text { - } & \text { Few core } \\
\text { locations } \\
\text { - } \quad \text { Local presence } \\
\text { for sales and } \\
\text { service }\end{array}$ & $\begin{array}{l}\text { Number of core } \\
\text { sites as well as } \\
\text { local sales and } \\
\text { service sites }\end{array}$ \\
\hline $\begin{array}{l}\text { Added value of } \\
\text { production }\end{array}$ & $\begin{array}{l}\text { Medium depth of } \\
\text { value added }\end{array}$ & $\begin{array}{l}\text { - Level of value } \\
\text { added }\end{array}$ \\
\hline $\begin{array}{l}\text { Performance- } \\
\text { oriented } \\
\text { organization with } \\
\text { continuous } \\
\text { leadership }\end{array}$ & $\begin{array}{l}\text { Performance } \\
\text { oriented } \\
\text { organization } \\
\text { Continuous } \\
\text { leadership of } \\
\text { management }\end{array}$ & $\begin{array}{l}\text { - } \quad \text { Length of service of } \\
\text { the management } \\
\text { Economic Value } \\
\text { Added (EVA) }\end{array}$ \\
\hline $\begin{array}{l}\text { - Optimized } \\
\text { R\&D } \\
\text { allocation }\end{array}$ & $\begin{array}{l}\text { - } \quad \text { Long-term and } \\
\text { continuous } \\
\text { development } \\
\text { activities } \\
\text { Balanced ratio } \\
\text { between } \\
\text { customer- } \\
\text { specific and } \\
\text { customer- } \\
\text { neutral } \\
\text { developments } \\
\text { Significant and } \\
\text { stable } \\
\text { investments in } \\
\text { development } \\
\text { activities }\end{array}$ & $\begin{array}{l}\text { - } \quad \text { Annual R\&D } \\
\text { investment based } \\
\text { on the company's } \\
\text { sales } \\
\text { - } \quad \text { Annual R\&D activity } \\
\text { costs } \\
\text { - Cost allocation of } \\
\text { customer-specific } \\
\text { and customer- } \\
\text { neutral } \\
\text { developments }\end{array}$ \\
\hline $\begin{array}{r}\text { - Integrated } \\
\text { supplier } \\
\text { network }\end{array}$ & $\begin{array}{l}\text { Suppliers are } \\
\text { intensively } \\
\text { integrated in the } \\
\text { value creation }\end{array}$ & $\begin{array}{ll}\text { - } & \text { Supplier } \\
& \text { qualification based } \\
\text { on: } \\
\text { - } & \text { Quantity output; } \\
\text { - } & \text { Quality } \\
& \text { performance; } \\
\text { - } & \text { Logistics service; }\end{array}$ \\
\hline
\end{tabular}

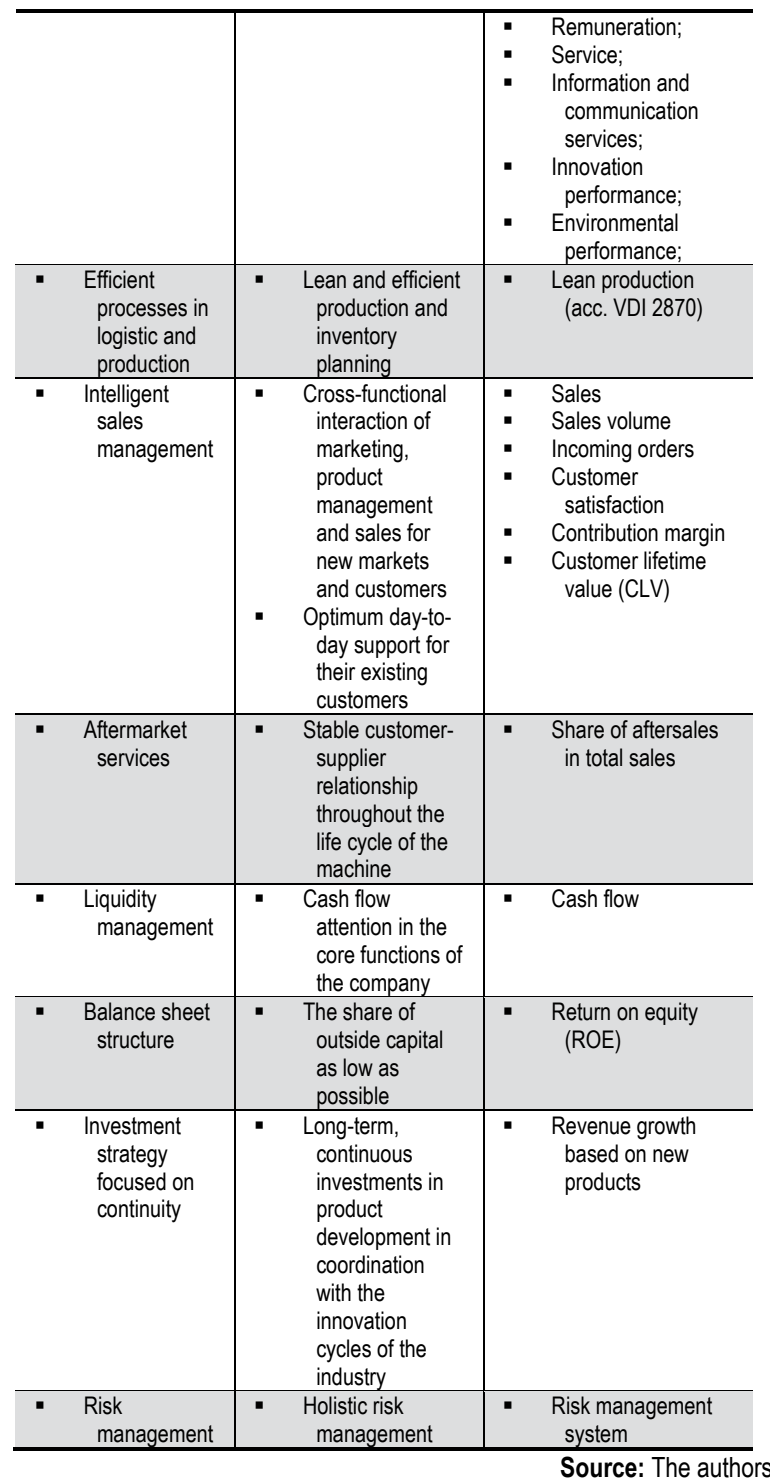

\subsubsection{KPIs based on success patterns according} McKinsey \& Company and VDMA (2014)

As previously mentioned, McKinsey \& Company and VDMA (2014) have identified the majority of their KPIs as the basis of their success patterns in the course of their analysis. Table 11 shows a summary and comparison of the individual patterns and their KPIs.

Table 11 Success patterns according to McKinsey \& Company and VDMA (2014) described by KPIs

\begin{tabular}{|c|c|}
\hline $\begin{array}{l}\text { Success pattern } \\
\text { according McKinsey \& } \\
\text { Company and VDMA } \\
\text { (2014) }\end{array}$ & $\begin{array}{l}\text { KPIs based on McKinsey \& Company } \\
\text { and VDMA (2014) }\end{array}$ \\
\hline $\begin{array}{c}\text { - Company size in } \\
\text { terms of sales }\end{array}$ & - Company size in terms of sales \\
\hline - Internationalization & - $\quad$ Share of sales outside Germany \\
\hline $\begin{array}{r}\text { - Operational } \\
\text { excellence }\end{array}$ & $\begin{array}{l}\text { - Delivery reliability } \\
\text { - Sumber of customer complaints } \\
\text { - Sales to sales and administrative }\end{array}$ \\
\hline
\end{tabular}




\begin{tabular}{|c|c|}
\hline & expenses ratio (SAE) \\
\hline $\begin{array}{l}\text { - } \quad \text { Stringency in the } \\
\text { business model }\end{array}$ & $\begin{array}{l}\text { - Share of core business in total } \\
\text { sales }\end{array}$ \\
\hline Innovation capability & - Innovation leadership \\
\hline Premium supplier & - Premium prices \\
\hline $\begin{array}{l}\text { - Single } \\
\text { machines/compon } \\
\text { ents }\end{array}$ & $\begin{array}{l}\text { - Share of standardized products in } \\
\text { total sales (in relation to } \\
\text { individualized products) }\end{array}$ \\
\hline Aftersales/service & - Share of aftersales in total sales \\
\hline - Industry affiliation & - Industry affiliation \\
\hline $\begin{array}{l}\text { - Ownership and } \\
\text { management } \\
\text { structure }\end{array}$ & - Type of company management \\
\hline
\end{tabular}

Source: The authors

Table 12 shows the consolidated KPIs and their success patterns according Eisenhut and Lässig (2013) of table 10, and McKinsey \& Company and VDMA (2014) of table 11. The two success patterns, innovation capability and innovation leader, are combined, as their KPIs are similar. This also applies to the patterns: Premium supplier and Product positioning, Aftersales service and Aftermarket services, and company size in terms of sales and sales. Overall 41 different KPIs are identified and grouped into the dimensions: Company, Finance, R\&D, Product, and Process and Functions.

Table 12 Consolidated KPIs and their success patterns, categorized into the dimensions: Company, Finance, R\&D, Product, and Process and Functions.

\begin{tabular}{|c|c|c|}
\hline \multicolumn{2}{|c|}{ Success Pattern } & KPIs \\
\hline \multirow[b]{5}{*}{ 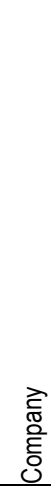 } & - Industry affiliation & - Industry affiliation \\
\hline & $\begin{array}{c}\text { - } \quad \text { Company size in } \\
\text { terms of sales }\end{array}$ & $\begin{array}{l}\text { - Company size in terms of } \\
\text { sales }\end{array}$ \\
\hline & $\begin{array}{l}\text { - } \begin{array}{l}\text { Ownership and } \\
\text { management } \\
\text { structure }\end{array} \\
\end{array}$ & $\begin{array}{l}\text { - Type of company } \\
\text { management }\end{array}$ \\
\hline & $\begin{array}{l}\text { Performance- } \\
\text { oriented } \\
\text { organization with } \\
\text { continuous } \\
\text { leadership }\end{array}$ & $\begin{array}{l}\text { - Length of service of the } \\
\text { management }\end{array}$ \\
\hline & $\begin{array}{l}\text { - } \quad \text { Global market } \\
\text { coverage with } \\
\text { locally adapted } \\
\text { structures }\end{array}$ & $\begin{array}{l}\text { - } \quad \text { Number of core sites as well } \\
\text { as local sales and service } \\
\text { sites }\end{array}$ \\
\hline \multirow{7}{*}{ 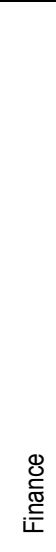 } & - $\quad$ Company growth & - $\quad$ Annual organic sales growth \\
\hline & $\begin{array}{c}\text { Intelligent sales } \\
\text { management }\end{array}$ & $\begin{array}{ll}\text { - } & \text { Sales volume } \\
\text { - } & \text { Incoming orders } \\
\text { - } & \text { Contribution margin }\end{array}$ \\
\hline & $\begin{array}{l}\text { - } \quad \text { Liquidity } \\
\text { management }\end{array}$ & - $\quad$ Cash flow \\
\hline & $\begin{array}{l}\text { Performance- } \\
\text { oriented } \\
\text { organization with } \\
\text { continuous } \\
\text { leadership }\end{array}$ & $\begin{array}{l}\text { - Economic Value Added } \\
\text { (EVA) }\end{array}$ \\
\hline & $\begin{array}{c}\text { - } \begin{array}{c}\text { Balance sheet } \\
\text { structure }\end{array} \\
\end{array}$ & - $\quad$ Return on equity (ROE) \\
\hline & - Internationalization & $\begin{array}{l}\text { - Share of sales outside } \\
\text { Germany }\end{array}$ \\
\hline & $\begin{array}{c}\text { - Aftermarket } \\
\text { services }\end{array}$ & $\begin{array}{l}\text { - } \begin{array}{l}\text { Share of aftersales in total } \\
\text { sales }\end{array} \\
\end{array}$ \\
\hline
\end{tabular}

\begin{tabular}{|c|c|c|}
\hline & $\begin{array}{l}\text { - Value-added } \\
\text { strategy }\end{array}$ & - Level of value added \\
\hline & $\begin{array}{r}\text { - Operational } \\
\text { excellence }\end{array}$ & $\begin{array}{l}\text { - Sales to sales and } \\
\text { administrative expenses } \\
\text { ratio (SAE) }\end{array}$ \\
\hline & - Innovation leader & $\begin{array}{l}\text { Number of patents per year } \\
\text { (submitted, pending and } \\
\text { approved) } \\
\text { - Share of new products in the } \\
\text { product range } \\
\text { - } \quad \text { Number of new products per } \\
\text { Euro spent on R\&D } \\
\text { - } \quad \text { Number of new products per } \\
\text { R\&D employee } \\
\text { - Sales of new products per } \\
\text { R\&D employee } \\
\text { - Revenue share of new } \\
\text { products } \\
\text { - Profit share of new products } \\
\text { Market share of new } \\
\text { - Cuducts } \\
\text { - } \text { products } \\
\text { Revenue growth based on } \\
\text { new products } \\
\text { Market share growth based } \\
\text { on new products } \\
\text { - Return on Innovation } \\
\text { Investment (ROII) }\end{array}$ \\
\hline 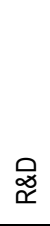 & $\begin{array}{l}\text { - Optimized R\&D } \\
\text { allocation }\end{array}$ & $\begin{array}{l}\text { - } \quad \text { Annual R\&D investment } \\
\text { based on the company's } \\
\text { sales } \\
\text { - } \quad \text { Annual R\&D activity costs } \\
\text { - } \quad \text { Cost allocation of customer- } \\
\text { specific and customer- } \\
\text { neutral developments }\end{array}$ \\
\hline & - $\quad$ Product positioning & - $\quad$ Premium prices \\
\hline & $\begin{array}{r}\text { - } \begin{array}{r}\text { Stringency in the } \\
\text { business model }\end{array} \\
\end{array}$ & $\begin{array}{l}\text { - Share of core business in } \\
\text { total sales }\end{array}$ \\
\hline 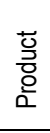 & $\begin{array}{l}\text { Single } \\
\text { machines/compo } \\
\text { nents }\end{array}$ & $\begin{array}{l}\text { Share of standardized } \\
\text { products in total sales (in } \\
\text { relation to individualized } \\
\text { products) }\end{array}$ \\
\hline \multirow{5}{*}{ 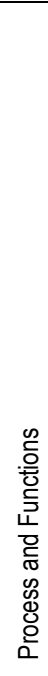 } & $\begin{array}{r}\text { Operational } \\
\text { excellence }\end{array}$ & $\begin{array}{l}\text { - } \quad \text { Delivery reliability } \\
\text { - } \quad \text { Number of customer } \\
\text { complaints }\end{array}$ \\
\hline & $\begin{array}{l}\text { - Integrated supplier } \\
\text { network }\end{array}$ & $\begin{array}{ll} & \text { Supplier qualification based } \\
& \text { on supplier's: } \\
\text { - } & \text { Quantity output; } \\
\text { - } & \text { Quality performance; } \\
\text { - } & \text { Logistics service; } \\
\text { - } & \text { Remuneration; } \\
\text { - } & \text { Service; } \\
\text { - } & \text { Information and } \\
\text { - } & \text { Innommunication services; } \\
\text { - } & \text { Environmental performance; }\end{array}$ \\
\hline & $\begin{array}{l}\text { Efficient processes } \\
\text { in logistic and } \\
\text { production }\end{array}$ & $\begin{array}{l}\text { - Lean production (acc. VDI } \\
2870 \text { ) }\end{array}$ \\
\hline & $\begin{array}{c}\text { Intelligent sales } \\
\text { management }\end{array}$ & $\begin{array}{l}\text { - } \quad \text { Customer satisfaction } \\
\text { - } \\
\text { (CLV) }\end{array}$ \\
\hline & - $\quad$ Risk management & - $\quad$ Risk management system \\
\hline
\end{tabular}

Source: The authors 


\section{Correlation between business models and KPIs}

In this section, a relationship is determined between the individual elements of the five business models' dimensions from section 2.2 and the consolidated KPIs from Table 12. Table 13 summarizes the description of the 41 determined KPIs

Table 13 Description of the $41 \mathrm{KPIs}$

\begin{tabular}{|c|c|c|}
\hline \multicolumn{2}{|l|}{ KPIs } & This KPI considers... \\
\hline \multirow[b]{5}{*}{ 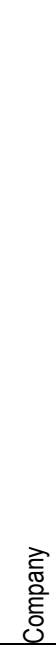 } & Industry affiliation & $\begin{array}{l}\text {...the company's average sector- } \\
\text { dependent profitability as it differs from } \\
\text { sector to sector in Germany's } \\
\text { engineering industry. }\end{array}$ \\
\hline & $\begin{array}{l}\text { Company size in } \\
\text { terms of sales }\end{array}$ & $\begin{array}{l}\text {... the company's size in terms of sales, } \\
\text { as companies tend to become more } \\
\text { profitable with increasing size due to } \\
\text { standardization and economies of } \\
\text { scale. }\end{array}$ \\
\hline & $\begin{array}{l}\text { Type of company } \\
\text { management }\end{array}$ & $\begin{array}{l}\text {... the company's management type, } \\
\text { such as family-run or employed } \\
\text { management. }\end{array}$ \\
\hline & $\begin{array}{l}\text { Length of service } \\
\text { of the } \\
\text { management }\end{array}$ & $\begin{array}{l}\ldots \text { the continuous management of the } \\
\text { company by length of its employment } \\
\text { with the company. }\end{array}$ \\
\hline & $\begin{array}{l}\text { Number of core } \\
\text { sites as well as } \\
\text { local sales and } \\
\text { service sites }\end{array}$ & $\begin{array}{l}\text {... corporate structure, with global } \\
\text { market coverage and locally adapted } \\
\text { structures, defined by a few core } \\
\text { locations and local presence for sales } \\
\text { and service. }\end{array}$ \\
\hline \multirow[b]{5}{*}{ 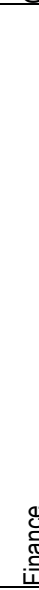 } & $\begin{array}{l}\text { Annual organic } \\
\text { sales growth }\end{array}$ & $\begin{array}{l}\text {...the company's annual organic growth } \\
\text { measured by its annual sales growth. } \\
\text { The focus is exclusively on the } \\
\text { company's own resources and internal } \\
\text { value-added processes used for growth. }\end{array}$ \\
\hline & Sales volume & $\begin{array}{l}\text {...the total annual amount of the } \\
\text { company's sold products. }\end{array}$ \\
\hline & Incoming orders & $\begin{array}{l}\text {...the total annual amount of incoming } \\
\text { orders. }\end{array}$ \\
\hline & $\begin{array}{l}\text { Contribution } \\
\text { margin }\end{array}$ & $\begin{array}{l}\text {... contribution margin, as the difference } \\
\text { between the revenue and the variable } \\
\text { costs of a good, which remains to cover } \\
\text { all other costs and as profit. }\end{array}$ \\
\hline & Cash flow & $\begin{array}{l}\text {... cash flow, as the financial surplus of } \\
\text { payments received in the course of a } \\
\text { company's business operations over } \\
\text { payments made in the same accounting } \\
\text { period. }\end{array}$ \\
\hline \multirow{5}{*}{ 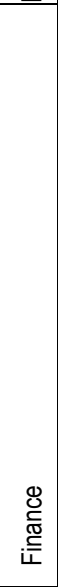 } & $\begin{array}{l}\text { Economic Value } \\
\text { Added (EVA) }\end{array}$ & $\begin{array}{l}\text {...EVA, used to measure the } \\
\text { performance of the company. It } \\
\text { calculates the period-related difference } \\
\text { between the business profit generated } \\
\text { by the capital employed and the costs } \\
\text { of a company associated with the } \\
\text { capital employed. }\end{array}$ \\
\hline & $\begin{array}{l}\text { Return on equity } \\
\text { (ROE) }\end{array}$ & $\begin{array}{l}\text {...ROE, measuring the income- } \\
\text { generating return on the equity that is } \\
\text { effective in the business operations of a } \\
\text { company on average over one year. }\end{array}$ \\
\hline & $\begin{array}{l}\text { Share of sales } \\
\text { outside Germany }\end{array}$ & $\begin{array}{l}\text {...the share of sales in total sales } \\
\text { generated outside Germany. }\end{array}$ \\
\hline & $\begin{array}{l}\text { Share of } \\
\text { aftersales in total } \\
\text { sales }\end{array}$ & $\begin{array}{l}\text {...the share of service sales in total } \\
\text { sales. }\end{array}$ \\
\hline & $\begin{array}{l}\text { Level of value } \\
\text { added }\end{array}$ & $\begin{array}{l}\text {...the level of the company's value } \\
\text { added. A company's value added refers }\end{array}$ \\
\hline
\end{tabular}

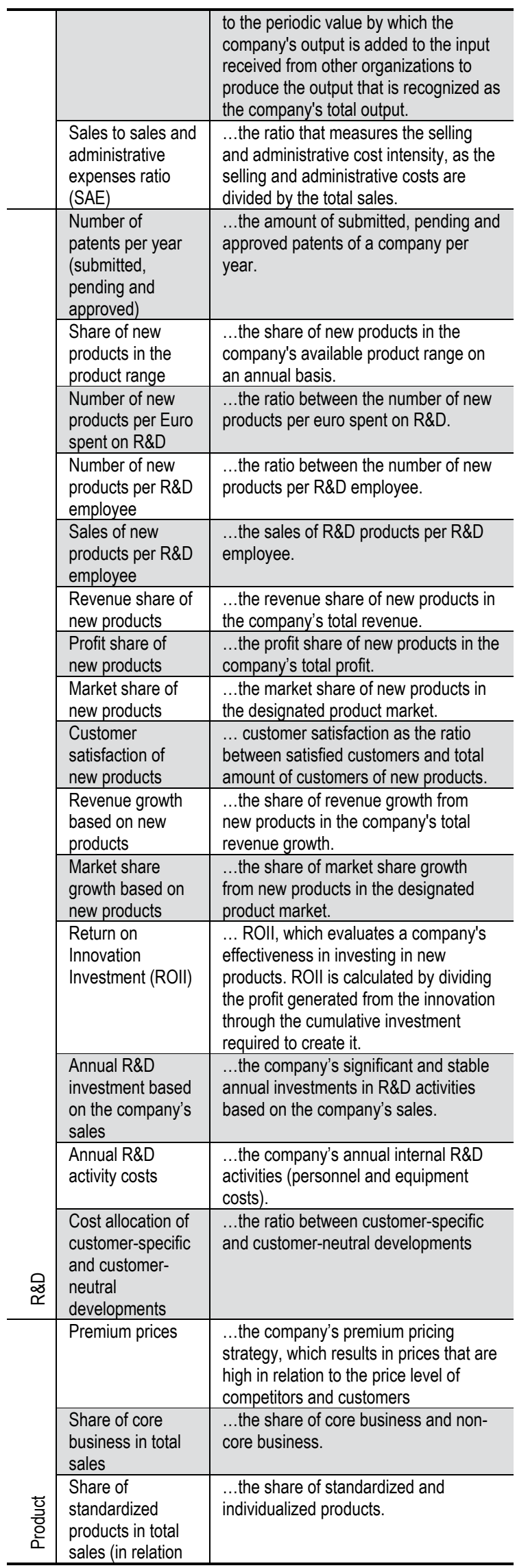




\begin{tabular}{|c|c|c|}
\hline & $\begin{array}{l}\text { to individualized } \\
\text { products) }\end{array}$ & \\
\hline \multirow{7}{*}{ 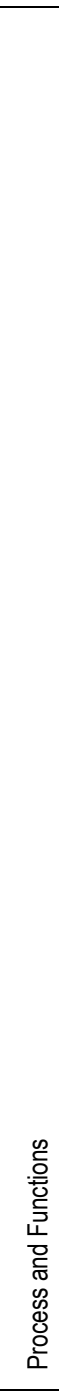 } & Delivery reliability & $\begin{array}{l}\text {... delivery reliability, measured by the } \\
\text { ratio of the quantity of on-time and } \\
\text { error-free deliveries divided by all } \\
\text { deliveries. }\end{array}$ \\
\hline & $\begin{array}{l}\text { Number of } \\
\text { customer } \\
\text { complaints }\end{array}$ & $\begin{array}{l}\text {...the amount of all customer } \\
\text { complaints. }\end{array}$ \\
\hline & $\begin{array}{l}\text { Supplier } \\
\text { qualification }\end{array}$ & $\begin{array}{l}\text {...the company's continuous supplier } \\
\text { qualification, which ensures the } \\
\text { supplier's quality. The qualification is } \\
\text { based on the eight following main } \\
\text { criteria for supplier evaluation: quantity } \\
\text { output, quality performance, logistics } \\
\text { service, remuneration, service, } \\
\text { information and communication } \\
\text { services, innovation performance and } \\
\text { environmental performance }\end{array}$ \\
\hline & $\begin{array}{l}\text { Lean production } \\
\text { (acc. VDI 2870) }\end{array}$ & $\begin{array}{l}\text {... a holistic production system, which is } \\
\text { a company-specific version of a } \\
\text { production system with elements of lean } \\
\text { production. This system is described in } \\
\text { VDI } 2870 \text { as a company-specific and } \\
\text { methodical set of guidelines. The } \\
\text { guideline consists of the following eight } \\
\text { design principles: avoidance of waste, } \\
\text { continuous improvement process, } \\
\text { standardization, zero-error principle, } \\
\text { flow principle, pull principle, employee } \\
\text { orientation and goal-oriented leadership } \\
\text { and visual management }\end{array}$ \\
\hline & $\begin{array}{l}\text { Customer } \\
\text { satisfaction }\end{array}$ & $\begin{array}{l}\text {... customer satisfaction as the ratio } \\
\text { between satisfied customers and total } \\
\text { amount of customers. }\end{array}$ \\
\hline & $\begin{array}{l}\text { Customer lifetime } \\
\text { value }(C L V)\end{array}$ & $\begin{array}{l}\text {...the contribution of a customer, } \\
\text { measured as the cash flow generated } \\
\text { by the customer during the entire } \\
\text { business relationship, can be } \\
\text { understood as Customer Lifetime Value } \\
\text { (CLV). }\end{array}$ \\
\hline & $\begin{array}{l}\text { Risk management } \\
\text { system }\end{array}$ & $\begin{array}{l}\text {... holistic risk management in a } \\
\text { corporate context, which systematically } \\
\text { analyses, evaluates, treats and controls } \\
\text { all corporate risks. }\end{array}$ \\
\hline
\end{tabular}

This determination is established by a comprehensive quantitative expert survey, as the available literature has limited data, showing a correlation between these two factors. The data is collected by multiple-choice questions, which the experts answered subjectively. The selection of these experts in German engineering industry was based on their professional experience of over 5 years, and their respective function in their company's business model. The experts include roles such as such as Vice President Finance / Controlling, Head of Sales, Head of Order Processing, Vice President Business Development, Head of Aftersales and Chief Operating Officer.

The correlation is defined by the respective rating of the individual KPI. Each respondent assessed whether the KPI is very important, important or neutral for the business model's dimensions under consideration. A total of 10 experts from various sectors of German engineering industry, such as electrical automation, machine tools and manufacturing systems, robots + automation, and large industrial plant manufacturing participated in answering the questionnaire. Table 14 shows the overview of the number of respondents by business model archetype, company size and industry sector.

Table 14 Survey participants - Correlation of KPIs; Number of respondents by business model, company size and industry sector

\begin{tabular}{|c|c|c|c|c|c|c|}
\hline \multicolumn{7}{|c|}{$\begin{array}{l}\text { Number of respondents by archetype, company size, industry sector } \\
\text { (multiple choice), } \\
n=10 \text { participants }\end{array}$} \\
\hline 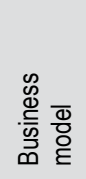 & 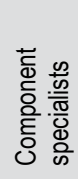 & 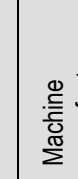 & & 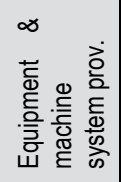 & 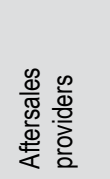 & 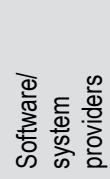 \\
\hline $\begin{array}{l}\dot{0} \\
\mathscr{\Phi}\end{array}$ & 5 & \multicolumn{2}{|l|}{4} & 7 & 9 & 8 \\
\hline 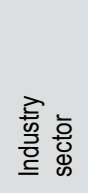 & 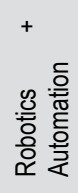 & \multicolumn{2}{|c|}{ 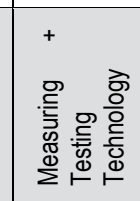 } & 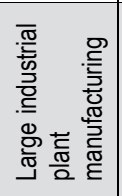 & 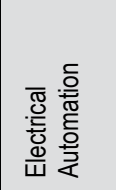 & 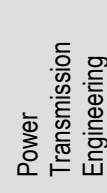 \\
\hline 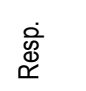 & 6 & \multicolumn{2}{|l|}{2} & 2 & 2 & 1 \\
\hline 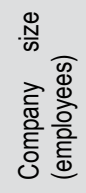 & $\begin{array}{l}< \\
1.000\end{array}$ & $\begin{array}{l}1.000 \\
- \\
1.500\end{array}$ & $\begin{array}{l}1.50 \\
- \\
5.00\end{array}$ & $\begin{array}{l}10.000 \\
- \\
15.000\end{array}$ & $\begin{array}{l}15.000 \\
- \\
20.000\end{array}$ & $\begin{array}{l}75.000- \\
100.000\end{array}$ \\
\hline 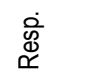 & 1 & 1 & 4 & 1 & 1 & 2 \\
\hline
\end{tabular}

The output of the survey does not show a clear result for each KPI, as some have an identical rating in the different classes (e.g. neutral, important and very important). As a result, these KPIs do not have a clear correlation to the respective business model. However, to enable an assessment of the significance of the individual KPIs, the following evaluation logic was applied. For KPIs with identical ratings in different categories (e.g. neutral, important and very important), the category with the highest importance was used. For example, if the categories, important and very important have the same ranking, the underlying KPI is rated very 
important. If, for example, the categories important and neutral have the same ranking, this KPI is rated as important. Following this logic, more KPIs tend to be categorizes as important or very important, but no ambiguous KPI is neglected.

Figure 7 shows the rating of the component specialists' KPIs based on the survey's results and application of the aforementioned evaluation logic. The respondents of this business model ranked 29 out of 41 KPIs as very important, 7 as important, and 5 as neutral. Within the company dimension, all KPIs are rated very important. All financial KPIs are regarded as very important, except for the two KPIs: cash flow, and share of aftersales in total sales. Cash flow is rated as important, whereas the share of aftersales in total sales is rated as neutral. The KPIs of the R\&D dimension present a much more differentiated picture. Overall, 4 R\&D KPIs are ranked neutral; these include number of patents, number of new products per $R \& D$ employee, sales per $R \& D$ employee, and annual R\&D activity costs. The remaining KPIs can be separated into two groups. One group, which includes number of new products per Euro spent, revenue, profit and market share of new products, and cost allocation for developments is categorized as important. The second group is categorized as very important, which includes share of new products in product range, customer satisfaction of new products, revenue and market share growth of new products, ROII, and annual R\&D investment is categorized as very important. The product dimension has only very important categorized KPIs, which is very similar for the dimension of process and functions. Besides CLV, which is ranked as important, all KPIs within this dimension are categorized as very important.

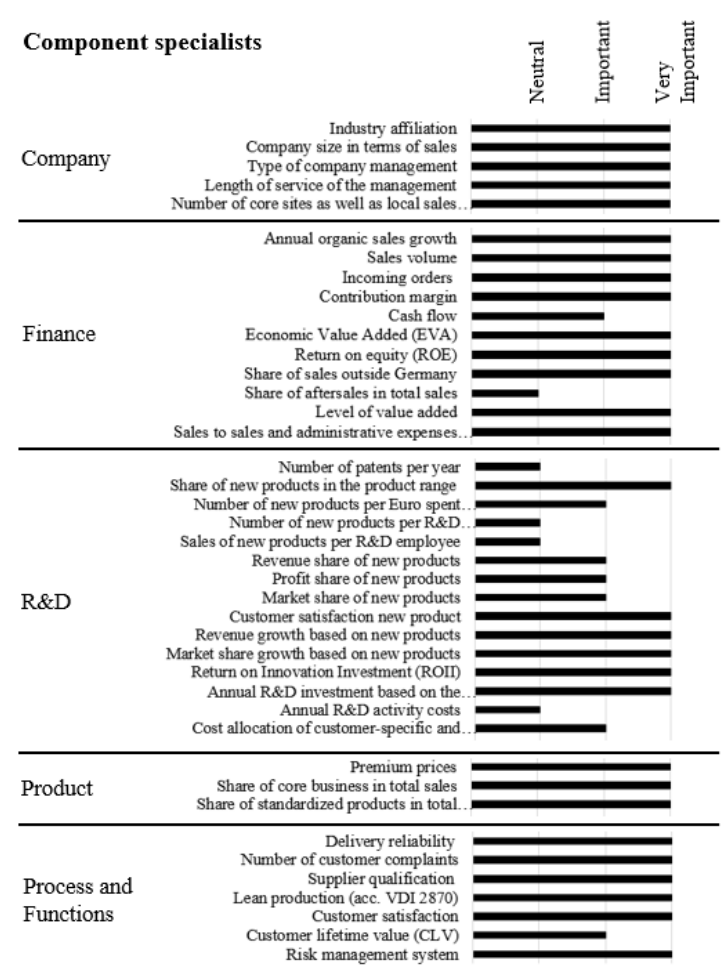

Figure 7 Rating of the component specialists' KPIs based on the survey

Source: The authors

Figure 8 presents the machine manufacturers' KPI rating with 23 categorized as very important, 10 as important, and 8 as neutral. All company's KPIs are categorized as very important, except the management type, which is ranked as neutral, and the industry affiliation, which is ranked as important. The financial KPIs' annual organic sales growth, and the SAE are categorized as neutral, whereas the contribution margin, and ROE are categorized as important. The remaining finance dimension's KPIs are categorized as very important. Within the R\&D dimension, the KPIs' ratings are comparable to those of the component specialists' business model. The number of patents, the number of new products per Euro spent or R\&D employee, the annual R\&D activity costs, and the cost allocation of developments are regarded as neutral. In contrast, the KPIs, customer satisfaction of new products, revenue and market share growth of new products, and the ROI are categorized as very important. The remaining KPIs of the R\&D dimension are categorized as important. The KPIs of the two dimensions, product, and process and functions, are categorized as very important. The premium prices KPI is declared as important.

Figure 9 summarizes the rating of the 
equipment \& machine system providers' KPIs. Overall, 22 of 41 KPIs are categorized as very important, 11 as important, and 8 as neutral. The respondents see the company size, and the management's service length as very important. In contrast, the number of core sites KPI is considered as neutral, and the KPIs management type and industry affiliation are categorized as important. The following finance dimension's four KPIs are clearly not categorized as very important. The ROE, the share of aftersales, and the SAE are considered as important. The level of value added KPI is regarded as neutral. The ratings of all KPIs within the R\&D dimension are identical to those of the machine manufacturers' business model. However, the KPI annual R\&D investment based on the company's sale is classified as very important. The two dimensions, product, and process and functions, include only premium prices and lean production, which are not regarded as very important. Premium prices KPI is considered as neutral, while lean production is ranked as important.

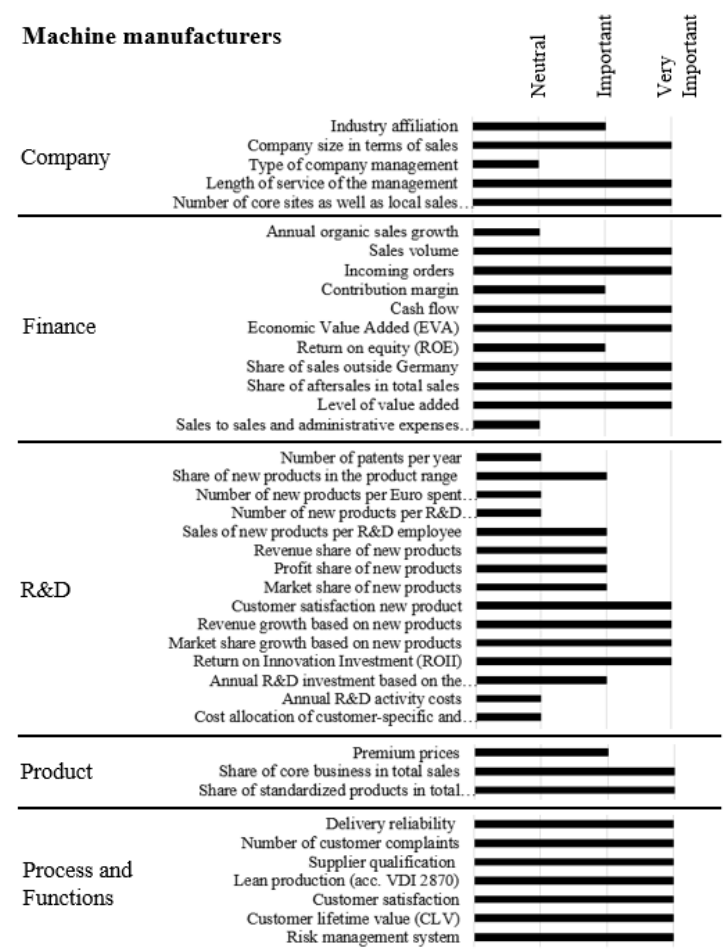

Figure 8 Rating of the machine manufacturers' KPIs based on the survey

Source: The authors

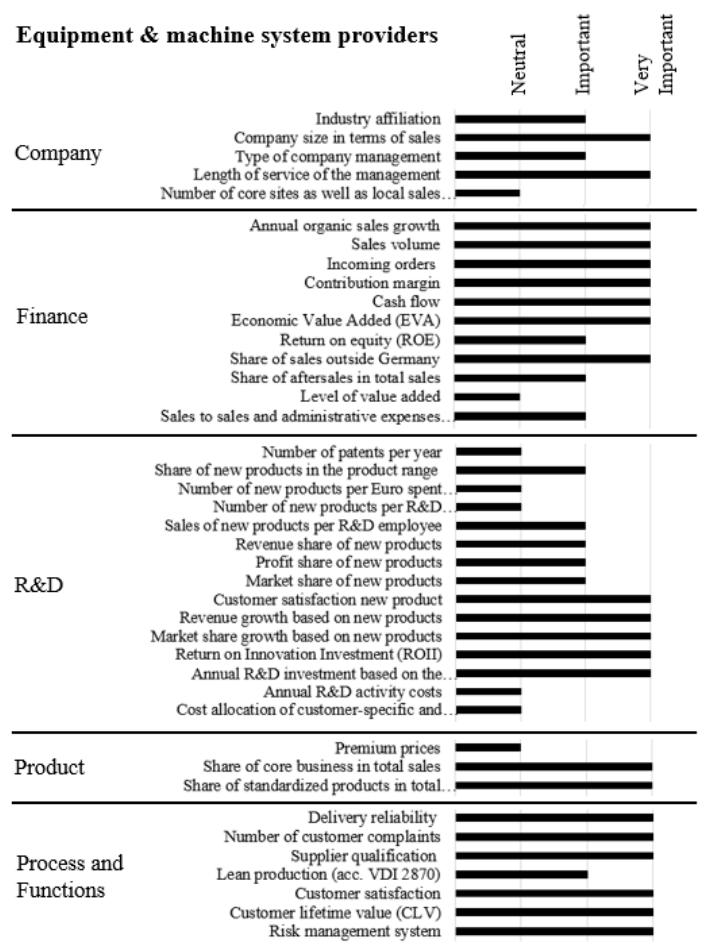

Figure 9 Rating of the equipment and machine system providers' KPIs based on the survey

Source: The authors

Figure 10 shows the respondents' evaluation for the correlation of the KPIs and the aftersales providers' business model. This evaluation consists of $40 \mathrm{KPIs}$, as the share of aftersales in total sales KPI is not considered. 21 of the 40 KPIs are rated as very important, 10 as important, and 9 as neutral. Two of the company's KPIs, industry affiliation and number of core sites, are categorized as very important. Three of the company's KPIs, company size, type of management and length of management service, are categorized as important. The financial KPIs are identical to the equipment \& machine system providers' rating of the same dimension. The difference is that the share of aftersales in total sales is not considered. An examination of the result of the R\&D dimension shows that almost half of the KPIs, 7 out of 15, are categorized as neutral. The remaining 8 KPIs can be separated into two groups, with each consisting of 4 KPIs. The first group consists of the important KPIs, such as share of new products in the product range, profit and market share of new products, and annual R\&D investment based on the company's sales. The second group are customer satisfaction, revenue and market share growth based on new products, and ROII, which are similarly categorized as very important. Both dimensions' KPIs ratings, i.e. product and process 
and functions are identical to those of the equipment \& machine system providers' business model.

The software/system providers' KPI rating is shown in figure 11, with 24 KPIs positioned as very important, 11 as important, and 6 as neutral. The company dimension has only one categorized very important KPI - the length of the management service. Industry affiliation, company size, and management type KPIs are categorized as important, and number of core sites is categorized as neutral. All financial KPIs are categorized as very important, except the SAE, which is categorized as important. The respondents categorized $7 \quad$ R\&D $\quad$ KPIs as important. The number of patents, the number of new products per R\&D employee, the annual R\&D activity costs and the cost allocation of developments are categorized as neutral. In contrast, the share of new products in the product range, customer satisfaction, and revenue and market share growth based on new product are categorized as very important. Only the premium prices are not categorized as very important within the product dimension, as it is declared neutral. All KPIs of the dimension process and functions are categorized as very important.

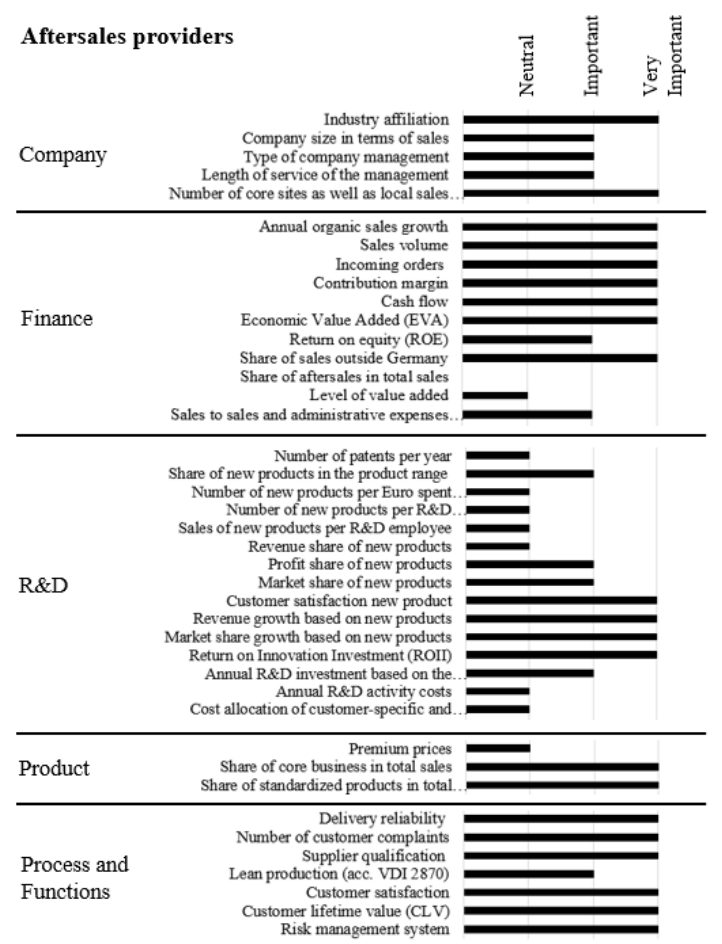

Figure 10 Rating of the aftersales providers' KPIs based on the survey

Source: The authors

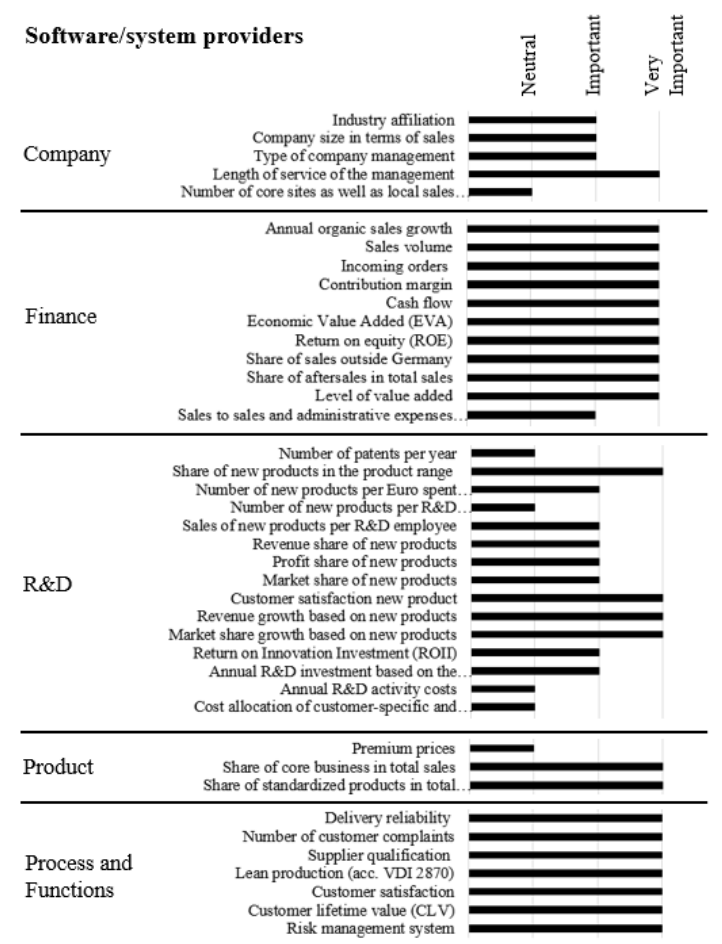

Figure 11 Rating of the software/system providers' KPIs based on the survey

Source: The authors

In summary, more than half of the classifications of KPIs vary between the five business models. However, there are some KPIs that have the same ranking across all business models. The financial KPIs, sales, sales volume, incoming orders, EVA, and share of sales outside Germany are all categorized as very important. Within the R\&D dimension, the number of patents per year, the number of new products per R\&D employee, and the annual R\&D activity costs are considered as neutral, whereas the customer satisfaction and the revenue and market share growth based on new products are regarded as very important. The profit and market share of new products are categorized as important. Furthermore, the KPIs share of core business, and share of standardized products of the dimension product are identical across all business models and are categorized as very important. Also, several KPIs of the process and functions dimension have identical rankings, such as delivery reliability, number of customer complaints, supplier qualification, customer satisfaction, and risk management, as they are classified as very important. 


\section{Conclusion}

The investigation of the degree of correlation of differently relevant KPIs, derived from industryspecific success patterns to German engineering industry's business models was substantiated by a quantitative expert survey. These results are based on the business models of German engineering industry, which were identified via a qualitative literature research and expert surveys. Their underlying description was done using the St. Gallen Business Model Navigator's explanation of a business model, which includes four dimensions: target customer, value proposition, value chain, and revenue model. The analysis of industry-specific success patterns is based on the evaluation of various quantitative studies on this topic. As a further step, these patterns were described by KPIs, based on relevant literature analysis.

The findings highlight the KPIs that are relevant to the respective business model, which enable a better understanding of the interrelationships of the business model in order to derive potential conclusions. A total of 41 KPIs were identified with different relevance for the considered business models. These KPIs were categorized in the different dimensions, such as company, finance, $\mathrm{R} \& \mathrm{D}$, product, and process and functions.

To strengthen the identified correlation between the KPIs and the business models, additional surveys should be conducted among industry experts. In order to evaluate the business models of the German engineering industry using the relevant KPIs, further research is required. Therefore, a model is necessary which would allow a comparison of company-specific KPIs values between different companies within the industry. In addition to the selection of the underlying data, it is also necessary to define the method in which the KPIs values of the companies are compared with each other. Furthermore, relevant methods are needed to incorporate the knowledge, gained from the benchmarking process with different companies, into the company's own strategy.

Another challenge is the validation of this methodology outside the German engineering industry. For this purpose, the identical method of the determination of business models, industryspecific KPIs and their correlation, could be used for another industry. Based on the described methodology for the evaluation of the business models of the German engineering industry, which has yet to be developed, these business models could then also be evaluated.sm

\section{References}

Afuah, A., \& Tucci, C. L. (2003). Internet Business Models and Strategies. New York: McGraw-Hill Higher Education.

Altmeier, M., Bauer, H., Becker, M., \& Simon, M. (2019). Changing market dynamics - Capturing value in machinery and industrial automation. McKinsey \& Company: McKinsey \& Company. Retrieved October 20, 2020, from

https://www.mckinsey.com/industries/advancedelectronics/our-insights/capturing-value-in-machineryand-industrial-automation-as-market-dynamics-change

Amit, R., \& Zott, C. (2001). Value creation in e-business. Strategic Management Journal (22), 493-520. https://doi.org/10.1002/smj.187

Aguilar, F. J. (1967). Scanning the business environment. Studies of the modern corporation. New York: Macmillan.

Ansoff, H. I., Kipley, D., Lewis, A. O., Helm-Stevens, R., \& Ansoff, R. (2019). Implanting Strategic Management, 3rd edition. Cham, Switzerland: Palgrave Macmillan. https://doi.org/10.1007/978-3-319-99599-1

Anthony, S. D. (2013, March 21). How to really measure a company's innovation prowess. Retrieved December 1, 2020, from Harvard Business Review: https://hbr.org/2013/03/how-to-really-measure-acompan

Arnold, G. (2013). Corporate Financial Management, Fifth edition. Harlow: Pearson Education Limited.

Bausch, U.-P., Buske, D., \& Hagemeier, W. (2011). Teil 3: Internationales Controlling im Kontext innovativer Controllingkonzepte. In W. Funk, \& J. Rossmanith, Internationale Rechnungslegung und Internationales Controlling (pp. 355-386). Wiesbaden: Gabler Verlag. https://doi.org/10.1007/978-3-8349-6465-6 11

Becker, W., \& Ulrich, P. (2011). Mittelstandsforschung Begriffe, Relevanz und Konsequenzen. Stuttgart: W. Kohlhammer $\mathrm{GmbH}$.

Becker, W., Ulrich, P., \& Stradtmann, M. (2018). Geschäftsmodellinnovationen als Wettbewerbsvorteil mittelständischer Unternehmen. Wiesbaden: Springer Gabler. https://doi.org/10.1007/978-3-658-13041-1

Boeing, C. (2001). Erfolgsfaktoren im Business-toConsumer-E-Commerce. Wiesbaden: Gabler. https://doi.org/10.1007/978-3-322-96453-3

Born, H.-J. (2018). Geschäftsmodell - Innovation im Zeitalter der vierten industriellen Revolution; Strategisches Management im Maschinenbau. Wiesbaden: Springer Vieweg. https://doi.org/10.1007/978-3-658-21171-4

Bornemann, M. (2010). Die Erfolgswirkung der Geschäftsmodellgestaltung - Eine kontextabhängige Betrachtung. Wiesbaden: Gabler Verlag. https://doi.org/10.1007/978-3-8349-8685-6

Bouwman, H., De Vos, H., \& Haaker, T. (2008). Mobile Service Innovation and Business Models. SpringerVerlag: Berlin Heidelberg. https://doi.org/10.1007/978-3-540-79238-3

Brauckmann, O. (2015). Smart Production - Wertschöpfung durch Geschäftsmodelle. Berlin: Springer Vieweg. https://doi.org/10.1007/978-3-662-45302-5 
Brauweiler, H.-C. (2019). Risikomanagement in Unternehmen - Ein grundlegender Überblick für die Management-Praxis. Wiesbaden: Springer Gabler. https://doi.org/10.1007/978-3-658-23480-5

Buhr, R. (1998, December). Use Case Maps as Architectural Entities for Complex Systems. IEEE Transactions on Software Engineering, 24(12), 11311155. https://doi.org/10.1109/32.738343

Capon, N., Farley, J. U., \& Hoenig, S. (1990, October). Determinants of Financial Performance: A MetaAnalysis. Management Science, 36(10), 1143-1159. https://doi.org/10.1287/mnsc.36.10.1143

CECIMO (ed.). (2011). Competitiveness of the European machine tool industry. Brussels: Filip Geerts. Retrieved October 15, 2020, from https://www.cecimo.eu/publications/study-on-thecompetitiveness-of-the-european-machine-tool-industry/

Chesbrough, H., \& Rosenbloom, R. S. (2002). The role of the business model in capturing value from innovation: evidence from Xerox Corporation's technology spin-off companies. Industrial and Corporate Change, 11(3), 529-555.

https://doi.org/10.1093/icc/11.3.529

CLAAS KGaA mbH. (2020). EASY - Efficient Agriculture Systems. Retrieved October 24, 2020, from CLAAS $\mathrm{KGaA} \mathrm{mbH}$ - Company homepage: https://www.claas.de/produkte/easy-2018-de

Daschmann, H.-A. (1994). Erfolgsfaktoren mittelständischer Unternehmen. Stuttgart: Schaeffer-Poeschel.

Delmar, F. (1997). Measuring Growth: Methodological Considerations and Empirical Results. In R. Donckels, \& A. Miettinen, Entrepreneurship and SME Research: On its Way to the Next Millennium (pp. 199-216). Aldershot: Ashgate Publishing Limited. https://doi.org/10.1016/S0022-0248(96)01071-8

Demont, A., \& Paulus-Rohmer, D. (2017). Industrie 4.0Geschäftsmodelle systematisch entwickeln. In D. Schallmo, A. Rusnjak, J. Anzengruber, T. Werani, \& M. Jünger, Digitale Transformation von Geschäftsmodellen - Grundlagen, Instrumente und Best Practices (pp. 97126). Wiesbaden: Springer Gabler. https://doi.org/10.1007/978-3-658-12388-8 4

Dombrowski, U., \& Mielke, T. (2015). Ganzheitliche Produktionssysteme - Aktueller Stand und zukünftige Entwicklungen. Berlin Heidelberg: Springer Vieweg. https://doi.org/10.1007/978-3-662-46164-8

Dr. Wieselhuber \& Partner $\mathrm{GmbH}$, \& Fraunhofer-IPA. (2015). Geschäftsmodell-Innovation durch Industrie 4.0 - Chancen und Risiken für den Maschinen- und Anlagenbau. Munich: Dr. Wieselhuber \& Partner GmbH. Retrieved October 12, 2020, from https://www.wieselhuber.de/migrate/attachments/Gesch aeftsmodell_Industrie40-Studie_Wieselhuber.pdf

Eisenhut, M., \& Lässig, R. (2013). Erfolgreich wie die Champions - Lernen vom deutschen Maschinenbau: Erfolgsmuster führen an die Spitze. Mainz: BrunoMedia $\mathrm{GmbH}$.

Fischer, M., Himme, A., \& Albers, S. (2007). Pionier, Früher Folger oder Später Folger: Welche Strategie verspricht den größten Erfolg? Zeitschrift für Betriebswirtschaft, 77(5), 539-573. https://doi.org/10.1007/s11573-007-0040-5

Forrester, J. W. (1968, May). Industrial Dynamics-A Response to Ansoff and Slevin. Management Science, 14(9), 601-618. https://doi.org/10.1287/mnsc.14.9.601
Gassmann, O., Frankenberg, K., \& Csik, M. (2017). Geschäftsmodelle entwickeln - 55 innovative Konzepte mit dem St. Gallener Business Model Navigator. München: Carl Hanser. https://doi.org/10.3139/9783446452848

Gebr. Heller Maschinenfabrik GmbH. (2020a). Finanzierungs- und Nutzungsmodelle im Überblick. Retrieved October 18, 2020, from Gebr. Heller Maschinenfabrik $\mathrm{GmbH}$ - Company homepage: https://www.heller.biz/de/services/finanzierung/

Gebr. Heller Maschinenfabrik GmbH. (2020b). HELLER4Use - Das neue Nutzungsmodell für mehr Flexibilität in Ihrer Fertigung. Retrieved October 18, 2020, from Gebr. Heller Maschinenfabrik GmbH Company homepage: https://www.heller.biz/de/maschinen-undloesungen/heller4use/

Gerl, S. (2020). Innovative Geschäftsmodelle für industrielle Smart Services - Ein Vorgehensmodell zur systematischen Entwicklung. Wiesbaden: Springer Gabler. https://doi.org/10.1007/978-3-658-29568-4

German Machine Tool Builders' Association (ed.). (2020). Market Report 2019 - The German Machine Tool Industry and its Position in the World Market. Mühlheim on the Main: H. Reuffurth Gmbh. Retrieved October 15, 2020, from https://vdw.de/en/press/publications/

Gitman, L. J., \& Zutter, C. J. (2012). Principles of Managerial Finance, 13th Edition. Boston: Pearson Education.

Gordijn, J., \& Akkermans, J. M. (2003, July). Value-based requirements engineering: exploring innovative ecommerce ideas. Requirements Engineering (8), 114134.

https://doi.org/10.1007/s00766-003-0169-x

Grasl, O. (2009). Business Model Analysis - Method and Case Studies. Sipplingen: Bookstation $\mathrm{GmbH}$.

Retrieved October 10, 2020, from https://www.academia.edu/35378142/Business_model_ analysis_a_multimethod_approach

Haziri, F., Chovancová, M., \& Fetahu, F. (2019). Game mechanics and aesthetics differences for tangible and intangible goods provided via social media. Management \& Marketing. Challenges for the Knowledge Society, 14(2),176-187. https://doi.org/10.2478/mmcks-2019-0012

Heidelberger Druckmaschinen AG. (2020). Subskriptionsangebot von Heidelberg erfolgreich bei Kunden im Einsatz - Lensing Druck deutlich produktiver als geplant. Retrieved October 18, 2020, from Heidelberger Druckmaschinen AG - Company homepage:

https://www.heidelberg.com/global/de/about heidelberg /press_relations/press_release/press_release_details/pr ess_release_107264.jsp

Heim, R., \& Linden, M. (2012, January). Diskussionsbeiträge der Fakultät für Betriebswirtschaftslehre Mercator School of Management Universität Duisburg-Essen Nr. 375. Konzeption eines Rahmenwerks zur Gestaltung und Bewertung von Geschäftsmodellen. Duisburg: Universität Duisburg-Essen, Fakultät für Betriebswirtschaftslehre, Mercator School of Management, Lehrstuhl für Wirtschaftsinformatik insbesondere Business Intelligence. Retrieved October 10,2020 , from https://de.slideshare.net/RalfHeim/einframework-zur-gestaltung-und-bewertung-vongeschftsmodellen 
Hinterhuber, A., \& Liozu, S. M. (2018). Thoughts: premium pricing in B2C and B2B. Journal of Revenue \& Pricing Management, 17(4), 301-305.

https://doi.org/10.1057/s41272-018-0138-0

Horsti, A. (2007). Essays on electronic business models and their evaluation. Helsinki: HSE Print. Retrieved October 5, 2020, from http://epub.lib.aalto.fi/pdf/diss/a296.pdf

IHK Nürnberg für Mittelfranken (ed.). (2014). Wertschöpfungsketten der Automation-Branche. Nürnberg: IHK Nürnberg für Mittelfranken. Retrieved October 15, 2020, from https://www.ihknuernberg.de/de/media/PDF/MetropolregionNuernberg/wertschoepfungsketten-der-automationbranche.pdf

Jacobs, J. (2019). Produktlebenszyklusorientiertes Controlling am Beispiel des produktbezogenen Businessplans. Wiesbaden: Springer Gabler. https://doi.org/10.1007/978-3-658-24330-2

Janker, C. G. (2008). Multivariate Lieferantenbewertung Empirisch gestützte Konzeption eines anforderungsgerechten Bewertungssystems. Wiesbaden: Gabler Edition Wissenschaft. https://doi.org/10.1007/978-3-8349-8105-9

Jansen, S. A., \& Mast, C. (2014). Konvergente Geschäftsmodellinnovationen in Deutschland; Studienergebnisse zu Treibern, Hemmnissen und Erfolgsfaktoren. Zeitschrift Führung + Organisation, 83, 25-31.

Janssen, S., \& Möller, K. (2011, April). Erfolgreiche Steuerung von Innovationsprozessen und -projekten Ergebnisse einer empirischen Studie. Controlling \& Management, 55(2), 97-104. https://doi.org/10.1007/s12176-011-0031-9

Janssen, S., Moeller, K., \& Schlaefke, M. (2011). Using performance measures conceptually in innovation control. Journal of Management Control. 22(1), 107128.

https://doi.org/10.1007/s00187-011-0130-y

Känel, S. v. (2018). Betriebswirtschaftslehre - Eine Einführung. Wiesbaden: Springer Gabler. https://doi.org/10.1007/978-3-658-19959-3

Kaplan, R. S., \& Norton, D. P. (1992, January-February). The Balanced Scorecard-Measures that Drive Performance. Harvard Business Review, 71-79. Retrieved October 15, 2020, from https://hbr.org/1992/01/the-balanced-scorecardmeasures-that-drive-performance-2

LeshchenkoY.G., \& Ermolovskaya O.Y. (2019) Features of regulation of integrated and functional models of financial markets: the experience of Germany and France. Journal of International Economic Affairs, 9(4), 2419-2432. https://doi.org/10.18334/eo.9.4.41430

Liebherr-International Deutschland $\mathrm{GmbH}$. (2020). Mieten von Baumaschinen. Retrieved October 18, 2020, from Liebherr-International Deutschland $\mathrm{GmbH}$ - Company homepage: https://www.liebherr.com/de/deu/\%C3\%BCberliebherr/service-dienstleistungen/mieten-vonbaumaschinen/mieten-von-baumaschinen.html

Magretta, J. (2002, May). Why business models matter. Harvard Business Review, pp. 86-92. Retrieved October 5, 2020, from https://hbr.org/2002/05/whybusiness-models-matter
McKinsey \& Company (ed.). (2016). Reengineering construction equipment: From operations focused to customer centric. Advanced Industries. Retrieved October 15, 2020, from https://www.mckinsey.com/industries/automotive-andassembly/our-insights/toward-a-customer-centricconstruction-equipment-industry

McKinsey \& Company and VDMA. (2014a). Erfolgsmuster und Trends im deutschen Nahrungsmittel- und Verpackungsmaschinenbau - Handlungsansätze für mehr Wachstum und Profitabilität. McKinsey \& Company; Verband Deutscher Maschinen- und Anlagenbau e.V. Retrieved October 18, 2020, from http://nuv.vdma.org/viewer/-/v2article/render/38268990

McKinsey \& Company and VDMA. (2014b). Erfolgsmuster und Trends im deutschen Textilmaschinenbau Handlungsansätze für mehr Wachstum und Profitabilität. McKinsey \& Company; Verband Deutscher Maschinen- und Anlagenbau e.V. Retrieved October 18, 2020, from https://www.vdma.org/publikationen

McKinsey \& Company and VDMA. (2014c). Erfolgsmuster und Trends in der deutschen Robotik- und Automationsbranche - Handlungsansätze für mehr Wachstum und Profitabilität. McKinsey \& Company; Verband Deutscher Maschinen- und Anlagenbau e.V. etrieved October 18, 2020, from https://rua.vdma.org/downloads

McKinsey \& Company and VDMA. (2014d). Zukunftsperspektive deutscher Maschinenbau: Erfolgreich in einem dynamischen Umfeld agieren. McKinsey \& Company; Verband Deutscher Maschinenund Anlagenbau e.V. Retrieved October 15, 2020, from http://nuv.vdma.org/viewer/-/v2article/render/38268990

McKinsey \& Company and VDMA. (2016). How to succeed: Strategic options for European machinery; Shifting growth patterns, increasing pace of digitization, and organizational change. McKinsey \& Company; Verband Deutscher Maschinen- und Anlagenbau e.V. Retrieved October 18, 2020, from http://nuv.vdma.org/viewer//v2article/render/38268990

Montgomery, O. (2019, September 23). What Tesla's elon musk can teach you about supply chains. Retrieved October 03, 2020, from Software Advice: https://www.softwareadvice.com/resources/elon-musktesla-supply-chain-lessons/

Morris, M., Schindehutte, M., \& Allen, J. (2005). The entrepreneur's business model: toward a unified perspective. Journal of Business Research 58, 726735. https://doi.org/10.1016/j.jbusres.2003.11.001

Mücke, K. (2019, May 13). Trumpf: Disruptive Geschäftsmodelle - Bezahlen, was man braucht. Retrieved October 18, 2020, from Schweizer Maschinenmarkt: https://www.maschinenmarkt.ch/bezahlen-was-manbraucht-a-828764/

Nicolai, A., \& Kieser, A. (2002). Trotz eklatanter Erfolglosigkeit: Die Erfolgsfaktorenforschung weiter auf Erfolgskurs - Erfolgsfaktoren; Managementforschung; Methoden; Praxisrelevanz. Die Betriebswirtschaft, 62(6), 579-596.

Österle, H., \& Winter, R. (2003). Business Engineering - Auf dem Weg zum Unternehmen des Informationszeitalters. Berlin Heidelberg: Springer-Verlag.

Osterwalder, A., \& Pigneur, Y. (2011). Business Model Generation - Ein Handbuch für Visionäre, Spielveränderer und Herausforderer. Frankfurt am Main: Campus Verlag $\mathrm{GmbH}$. 
Osterwalder, A., Pigneur, Y., \& Tucci, C. L. (2005) Clarifying business models: origins, present, and future of the concept. Communications of the Association for Information Systems, 15, 1-25. https://doi.org/10.17705/1CAIS.01601

Palumbo, D. (2019, July 05). Amazon at 25: The story of a giant. Retrieved October 03, 2020, from BBC News: https://www.bbc.com/news/business-48884596

Pateli, A. G., \& Giaglis, G. M. (2003). A Framework for Understanding and Analysing eBusiness Models. 16th Bled eCommerce Conference eTransformation, (pp. 329-348). Bled, Slovenia.

Retrieved October 5, 2020, from

https://users.ionio.gr/ pateli/publications/Conferences/P DFs/(Pateli\%20\&\%20Giaglis,\%202003)\%20A\%20Fram ework\%20for\%20Understanding\%20and\%20A.pdf

Pateli, A. G., \& Giaglis, G. M. (2004). A research framework for analysing eBusiness models. European Journal of Information Systems, 13(4), 302-314. https://doi.org/10.1057/palgrave.eiis.3000513

Pufahl, M. (2019). Sales Performance Management Exzellenz im Vertrieb mit ganzheitlichen Steuerungskonzepten. Wiesbaden: Springer Gabler. https://doi.org/10.1007/978-3-658-23067-8

PwC and VDMA (ed.). (2019). Digital business models in plant engineering and construction in an international comparison - A benchmarking study of PwC and VDMA. Frankfurt on the Main: PricewaterhouseCoopers GmbH \& VDMA Large Industrial Plant Manufacturers' Group. Retrieved October 24, 2020, from https://www.pwc.de/de/industrielle-produktion/pwcvdma-studie-digital-business-models-in-plantengineering-and-construction.pdf

Sandrock, J. (2006). System Dynamics in der strategischen Planung - Zur Gestaltung von Geschäftsmodellen im ELearning. Wiesbaden: Deutscher Universitäts-verlag.

Saunila, M. (2017). Understanding innovation performance measurement in SMEs. Measuring Business

Excellence, 21(1), 1-16. https://doi.org/10.1108/MBE-01-2016-0005

Schallmo, D. R. (2018). Geschäftsmodelle erfolgreich entwickeln und implementieren. Berlin: Springer Gabler. https://doi.org/10.1007/978-3-662-57605-2

Schweiger, C. (2012). Junge Technologieunternehmen Systematische Personal- und Organisationsentwicklung. Wiesbaden: Springer Gabler. https://doi.org/10.1007/978-3-8349-3490-1

SICK AG. (2020). Smart Service Suite. Retrieved October 24, 2020, from SICK AG - Company homepage: https://www.sick.com/de/de/smart-service-suite-vonsick-mehrwert-fuer-die-digitalisierte-automationeinstieg-in-industrie-40-und-entwicklung-neuergeschaeftsmodelle-fuer-mehranlagenproduktivitaet/w/press-2018-automatica-smartservices/

Spelsberg, H. (2011). Die Erfolgsfaktoren familieninterner Unternehmensnachfolgen - Eine empirische Untersuchung anhand deutscher Familienunternehmen. Wiesbaden: Gabler. https://doi.org/10.1007/978-3-8349-6581-3
Subic, J., Vasiljevic, Z., \& Andrei, J. (2010). The impact of FDI on the European economic development in the context of diversification of capital flows. Proceedings of the 14th International Business Information Management Association, Business Transformation through Innovation and Knowledge Management: An Academic Perspective, Istanbul, Turkey, 23-24.

Thyssenkrupp Industrial Solutions AG. (2020). Digitized Expertise. Retrieved October 24, 2020, from thyssenkrup Industrial Solutions AG - Company homepage: https://www.thyssenkrupp-industrialsolutions.com/de/digitalized-expertise/evaluate-andpredict/

TRUMPF Financial Services. (2020). Auf einen Blick: Unsere Finanzierungsvarianten. Retrieved October 18 , 2020, from TRUMPF GmbH + Co. KG - Company homepage:

https://www.trumpf.com/de_DE/produkte/services/servic es-maschinen-systeme-und-laser/finanzierung/

Ulrich, P., \& Fibitz, A. (2017, October 01). Geschäftsmodellinnovationen - radikaler Wandel oder inkrementelle Verbesserung? Der Betriebswirt: Management in Wissenschaft und Praxis, 32-36. https://doi.org/10.3790/dbw.58.4.32

VDMA. (2020). Über den VDMA. Retrieved November 15, 2020, from VDMA - Organization homepage: http://www.vdma.org/ueber-den-vdma

VDMA Antriebstechnik und Fluidtechnik (ed.). (2017). Antriebstechnik und Fluidtechnik - Motion, Drive \& Automation. Frankfurt am Main: VDMA Verlag $\mathrm{GmbH}$. Retrieved October 15, 2020, from https://ant.vdma.org/

VDMA Elektrische Automation (ed.). (2018). Automation on Request (11th Edition). Frankfurt am Main: VDMA Verlag $\mathrm{GmbH}$. Retrieved October 15, 2020, from https://ea.vdma.org/viewer/-/v2article/render/15263617

VDMA Fachverband Kunststoff und Gummima. (ed.). (2019, June). Jahrestagung, Fachverband Kunststoff und Gummimaschinen. Jahresrückblick Kunststoff und Gummimaschinen. Retrieved October 18, 2020, from https://kug.vdma.org/statistik-und-konjunktur

VDMA Future Business (ed.). (2020). Deutscher Nahrungsmittel-Maschinenbau 2035 - BranchenZukunftsbilder für den Maschinen- und Anlagenbau. Mühlheim am Main: $\mathrm{H}$. Reuffurth $\mathrm{GmbH}$. Retrieved October 18, 2020, from https://nuv.vdma.org/viewer//v2article/render/48944270

VDMA Landtechnik (ed.). (2020). Landtechnik Geschäftsbericht 2016-2020. Frankfurt am Main: VDMA Verlags $\mathrm{GmbH}$. Retrieved October 18, 2020, from https://lt.vdma.org/viewer/-/v2article/render/52300491

VDMA Large Industrial Plant Man. Group (ed.). (2020). Status Report 2019/2020 - Creating sustainable success - Industrial plant manufacturing masters the change. Mühlheim on the Main: $\mathrm{H}$. Reuffurth $\mathrm{GmbH}$. Retrieved October 18, 2020, from http://agab.vdma.org/en/lagebericht_neu

VDMA Mess- und Prüftechnik (ed.). (2019). Das BranchenNetzwerk - Mitglieder und Produkte. Frankfurt am Main: VDMA Verlags $\mathrm{GmbH}$. Retrieved October 18, 2020, from https://mup.vdma.org/viewer//v2article/render/15190429 
VDMA Motoren und Systeme (ed.). (2019). Motoren und Systeme - Geschäftsbericht 2019. Frankfurt am Main: VDMA Verlags $\mathrm{GmbH}$. Retrieved October 18, 2020, from https://mus.vdma.org/presse-publikationen

VDMA Robotik + Automation (ed.). (2018). Robotik und Automation auf einen Blick - Die Branche - Der Fachverband - Die Hersteller. Frankfurt am Main: VDMA Verlags $\mathrm{GmbH}$. Retrieved October 18, 2020, from https://rua.vdma.org/

Voigt, K.-I., Arnold, C., Kiel, D., \& Müller, J. M. (2019). Geschäftsmodelle im Wandel durch Industrie 4.0 - Wie sich etablierte Industrieunternehmen in verschiedenen Branchen verändern. In R. Obermaier, Handbuch Industrie 4.0 und Digitale Transformation Betriebswirtschaftliche, technische und rechtliche Herausforderungen (pp. 355-378). Wiesbaden: Springer Gabler.

https://doi.org/10.1007/978-3-658-24576-4 16

Woywode, M. (2004). Wege aus der Erfolglosigkeit der Erfolgsfaktorenforschung. In K. Bankengruppe, Was erfolgreiche Unternehmen ausmacht - Erkenntnisse aus Wissenschaft und Praxis (pp. 15-48). Heidelberg: Physica-Verlag. https://doi.org/10.1007/978-3-7908-2714-9 2

\section{$\bowtie$ Correspondence}

\section{Konstantin B. Kostin}

Saint-Petersburg State University of Economics

Sadovaya str. 21, office 2094 St. Petersburg 191023, Russia

E-mail: kost_kos@mail.ru
Zimmermann, L. (2013). Erfolgsfaktoren der Geschäftsmodelle junger Unternehmen. Stuttgart: W. Kohlhammer $\mathrm{GmbH}$.

Zollenkop, M. (2006). Geschäftsmodellinnovation Initiierung eines systematischen Innovationsmanagements für Geschäftsmodelle auf Basis lebenszyklusorientierter Frühaufklärung. Wiesbaden: GWV Fachverlage $\mathrm{GmbH}$.

Zott, C., \& Amit, R. (2007, March-April). Business Model Design and the Performance of Entrepreneurial Firms. Organization Science, 18(2), 181-199. https://doi.org/10.1287/orsc.1060.0232

Zott, C., \& Amit, R. (2010). Business model design: an activity system perspective. Long Range Planning, 43, 216-226. https://doi.org/10.1016/j.Irp.2009.07.004

Zott, C., Amit, R., \& Massa, L. (2011). The Business Model: Recent Developments and Future Research. Journal of Management, 37(4), 1019-1042. https://doi.org/10.1177/0149206311406265 